\title{
Hydrogeology of Pumice-Hosted Fens in the Winema-Fremont National Forest, Oregon, USA
}

\author{
Michael L. Cummings, Jonathan M. Weatherford, Leslie A. Mowbray \\ Department of Geology, Portland State University, Portland, USA \\ Email: cumminm@pdx.edu
}

Received 31 October 2014; revised 20 November 2014; accepted 11 December 2014

Copyright (C) 2014 by authors and Scientific Research Publishing Inc.

This work is licensed under the Creative Commons Attribution International License (CC BY). http://creativecommons.org/licenses/by/4.0/

(c) (i) Open Access

\begin{abstract}
Subaerial fallout from the Holocene eruption of Mount Mazama in the Oregon Cascade Range was deposited upon relatively low permeability volcanic and volcaniclastic bedrock and regolith. In the Walker Rim study area, erosion by ephemeral streams shortly after the eruption disrupted the lateral continuity of the 270 to $300 \mathrm{~cm}$-thick pumice deposit. Co-evolution of the surface- and ground-water systems in a low-relief, low-slope landscape allowed diffuse groundwater discharge from the banks of the evolving stream system. Accumulation of organic material from groundwater dependent ecosystems at these sites of discharge allowed peat deposits to form on gently sloping erosion surfaces cut into the pumice deposit. Following early stream incision, fine-grained, silt-rich deposits accumulated in valleys and contributed permeability barriers to the lateral migration of water in the pumice aquifer. Fens discharge from the pumice aquifer through gently sloping surfaces patterned after the slope of the erosion surface cut into the pumice deposit and overlain by approximately $1 \mathrm{~m}$ of peat on the sloping surface and alluvium or iron-cemented pumice overlain by alluvium at the toe of the slope. The predominant source of groundwater is snowmelt which infiltrates the pumice deposit during the freshet. However, shallow groundwater flow also takes place along permeable pathways in bedrock units. Locally, low volume discharge takes place along faults. The snowmelt-dependent hydrologic system that supports the fens of the Walker Rim study area occurs at elevations primarily above $1585 \mathrm{~m}$.
\end{abstract}

\section{Keywords}

Groundwater Dependent Ecosystem, Fen, Pumice Aquifer, Mount Mazama, Oregon

\section{Introduction}

The responses of the surface- and ground-water systems to the eruption of Mount Mazama in the Cascade vol-

How to cite this paper: Cummings, M.L., Weatherford, J.M. and Mowbray, L.A. (2014) Hydrogeology of Pumice-Hosted Fens in the Winema-Fremont National Forest, Oregon, USA. Journal of Water Resource and Protection, 6, 1762-1780. 
canic arc of Oregon USA include failure of debris dams [1], capture of surface drainage by the groundwater system [2], floodplain adjustments [3], development of diverse wetlands including fens [4], and adjustment to groundwater and surface water contributions in the upper Klamath River basin [5] [6].

The fault scarps of Walker Rim define the western and northwestern margins of a recently (Pleistocene?) uplifted fault block located approximately 60 to $70 \mathrm{~km}$ north northeast of Mount Mazama (Crater Lake) (Figure 1). The Plinian or single-vent phase of the cataclysmic eruption of Mount Mazama [7] blanketed pre-eruption landscapes to the east and north-northeast of the volcano with pumice. In the Walker Rim area, the pumice deposit from this phase of the eruption is 2.7 to $3.0 \mathrm{~m}$ thick. The post-eruption response set the stage for the development of a pumice-hosted perched aquifer and the emergence of pumice-hosted fens that support diverse groundwater dependent ecosystems [4].

In this paper, we focus on the characteristics of the pumice deposit, bedrock geology, and identify the sources of the water that support the groundwater dependent ecosystems in the Walker Rim area. We discuss the ground- and surface-water system's response to burial beneath a blanket of pumice and the evolution of the perched aquifer and fen systems.

\section{Common Characteristics of Fen Systems}

The fens of the Walker Rim area have the following common characteristics. Discharge at all fens is from the pumice deposit formed during the cataclysmic eruption of Mount Mazama at 7700 yr. B.P. (B.P. $=$ before present, where present is AD 1950; $7627 \pm 150$ cal. yr. B.P. [8]). Discharge from the pumice aquifer takes place on gentle slopes where the normal lateral continuity of the pumice deposit has been disrupted by erosion. The erosion surface cross cuts the internal stratigraphy of the pumice deposit and is overlain by peat. Alluvium or iron-cemented pumice may be present at the toe of the sloping fen surface. The piezometric surfaces for the pumice aquifer are commonly above ground during the growing season and support diverse groundwater dependent ecosystems with bryophytes as abundant members of the plant community. The piezometric surfaces in peat are commonly at or slightly above the local ground surface. The groundwater discharge is dilute (electrical conductivity 25 to $45 \mu \mathrm{S} / \mathrm{cm}$ ), weakly acidic ( $\mathrm{pH}=6.2$ to 6.8 ), Na-bicarbonate water with few exceptions. $\mathrm{Pu}-$ mice-hosted fens are most commonly present at elevations greater than $1585 \mathrm{~m}$.

Four questions have guided the research into these fen systems. 1) What are the characteristics of the pumice deposit that support the diffuse discharge of groundwater at fens? 2) What are the characteristics of the bedrock and pre-eruption deposits that underlie the pumice deposit? 3) What is the source of the groundwater that discharges from the fens? And 4) how do the fens fit within the landscape response to the widespread disturbance produced by the eruption of Mount Mazama?

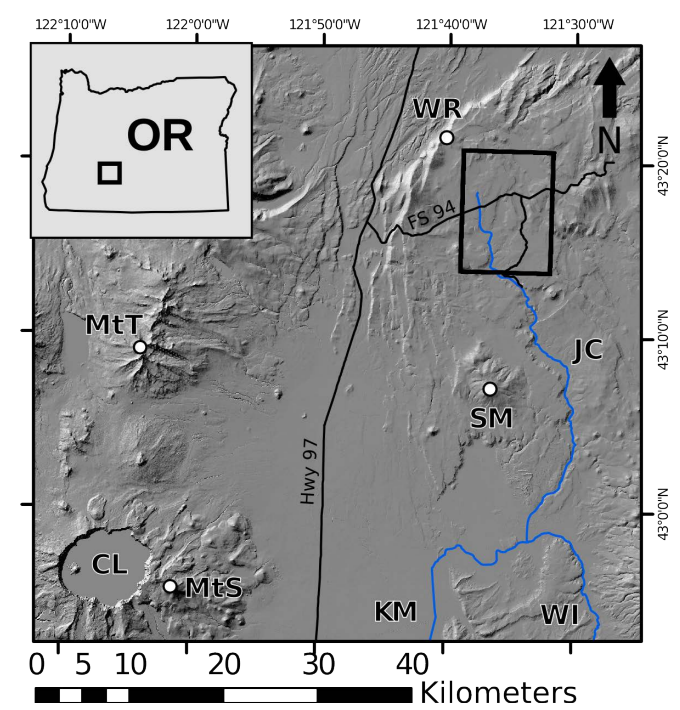

Figure 1. The Walker Rim study site is enclosed in the black rectangle. CL $=$ Crater Lake, MtS = Mount Scott, MtT = Mount Thielsen, $\mathrm{KM}=$ Klamath Marsh, WI = Williamson River, SM = Sugarpine Mountain, JC = Jack Creek, WR = Walker Rim. FS 94 = Forest Service Arterial Road 94. 


\subsection{Pumice Deposit}

The Walker Rim study area (Figure 1) was uniformly buried by 2.7 to $3.0 \mathrm{~m}$ of pumice during the single vent, Plinian phase, of the eruption of Mount Mazama at 7700 yr. B.P. In the study area, the pumice deposit is divided into a lower and upper unit based on grain size, sorting, and composition. The lower pumice unit is crystal- and lithic-rich at the base with pumice less than $0.3 \mathrm{~cm}$ in diameter. This basal layer is overlain by lithic- and crystal-bearing moderately well-sorted pumice that increases in grain size from $0.3 \mathrm{~cm}$ to $0.7 \mathrm{~cm}$ upward. At about $1.5 \mathrm{~m}$ above the base, the sorting in the lower pumice unit decreases with largest grains up to $1.5 \mathrm{~cm}$ in diameter and variable percentages of lithic and crystal fragments. The poorly sorted, 1 meter-thick upper pumice unit is comprised of pumice blocks ranging from $1 \mathrm{~cm}$ to over $7 \mathrm{~cm}$ in diameter. Crystal and lithic fragments are volumetrically sparse. The lower and upper pumice units in this study correlate to the upper pumice subdivision of the pumice deposit by Young [9]. An isopach map provided by Young [9] for his upper pumice unit indicates thickness near Round Meadow (Figure 2) is around $270 \mathrm{~cm}$.

The dynamics of the Plinian eruption from Mount Mazama [7] [10] produced a deposit characterized by lateral continuity of physical properties over the scale of the study area. Klug et al. [11] determined the structure and physical characteristics of pumice produced by the climactic eruption of Mount Mazama. The bulk vesicularity

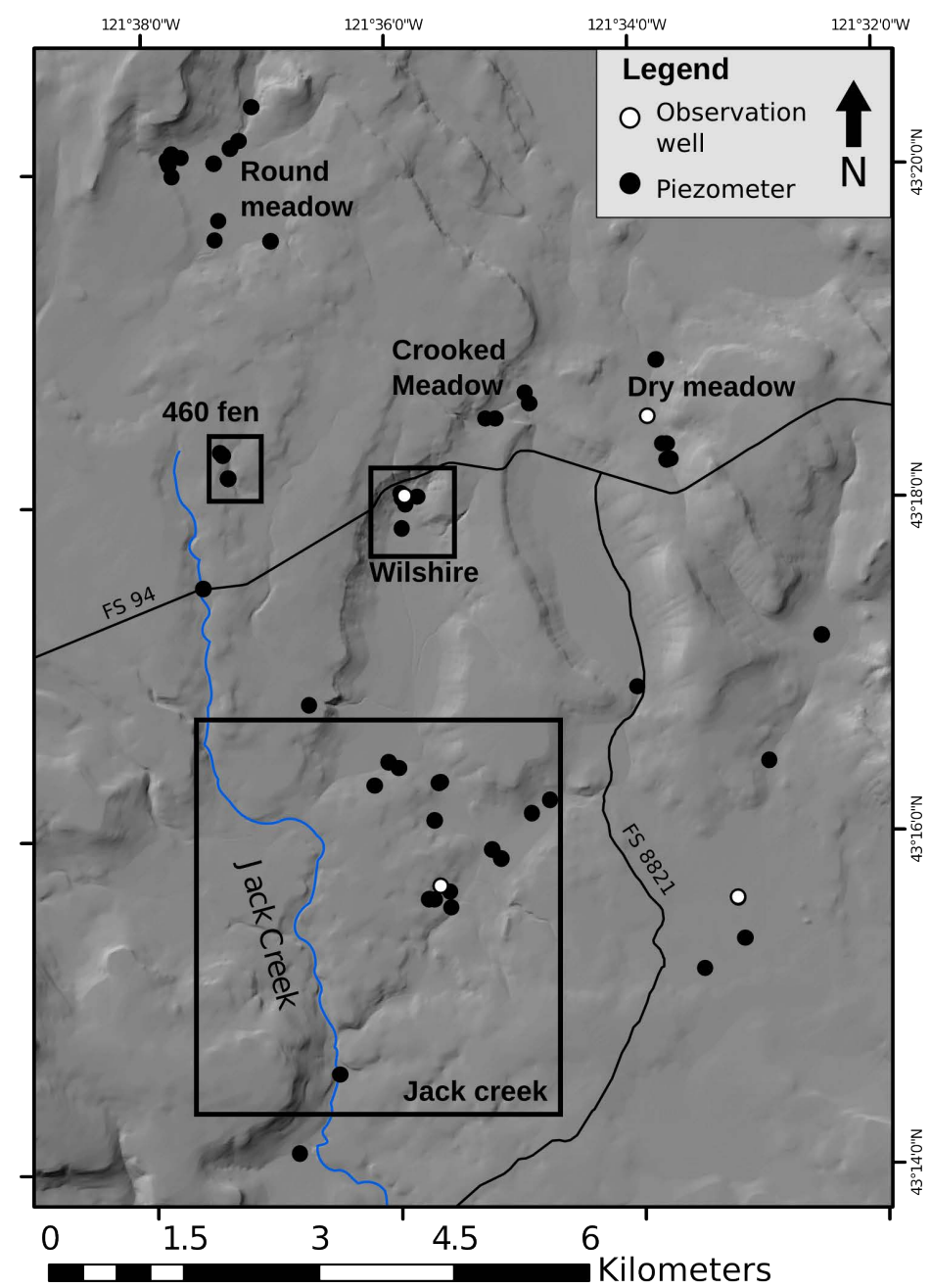

Figure 2. Location map for fen systems referred to in this paper. Rectangles show the location of maps presented in figures elsewhere in this paper. Black dots provide the location of shallow piezometers completed in the pumice aquifer and white dots provide the location of observations wells where bedrock stratigraphy was determined and water levels are monitored. 
of all pumice clasts is between 75 and 88 percent and all clasts have high pore interconnectivity ( $>90$ vol\%). Young [9] determined grain size throughout the subaerial fallout blanket. Hydraulic conductivity of the pumice deposit was estimated at $21.2 \mathrm{~m} / \mathrm{d}$ [4].

Since the eruption, the once uniform thickness of the pumice blanket has been modified. Lateral disruptions in thickness were produced by surface-water erosion in the post-eruption landscape. The simplest form of disruption occurs at abrupt slope breaks related to the differential hardness of bedrock units. Olivine basalt lava flows are more resistant to erosion than weakly lithified volcaniclastic sedimentary rocks, basalt hydrovolcanic deposits, and un-welded pyroclastic flows. Sites where outcrops of capping lava flows abruptly increased slope were the locus of preferential erosion that disrupted the continuity of the pumice blanket and in places define boundaries in the pumice aquifer.

The more significant disruptions to the pumice blanket relative to the surface- and ground-water systems are related to drainage development after the eruption. Down cutting by ephemeral streams disrupted the lateral continuity of the pumice blanket. The distribution and slopes of newly forming valleys were dictated by preeruption topography. Where slopes were greater in the pre-eruption landscape the pumice was stripped away to expose bedrock. Where slopes were gentle the coarse-grained upper pumice unit was commonly eroded leaving behind remnants of the lower pumice unit. Low density and buoyancy of pumice in water are unique characteristics that influenced erosion, transport, and deposition [12]. The low bulk density of dry pumice relative to water allowed flotation and, with transport, progressive rounding of pumice by abrasion. Abrasion produced glassy silt and liberated phenocrysts from the glassy framework of the pumice.

As the drainage development progressed, deposition came to dominate valley evolution. Lag deposits composed of crystals (formerly phenocrysts) and rock fragments winnowed from the primary pumice deposit were deposited directly on the remnants of the lower pumice. In ephemeral stream valleys the lag deposits grade upward into rounded grains of pumice (sand to pebble) in a matrix of glassy silt.

In addition to physical disruption of the pumice blanket by erosion, permeability reductions at 1) contacts between primary pumice deposits and alluvium, 2) zones of iron precipitation, and 3) deposition of organic material to form peat deposits restrict lateral water movement in the pumice aquifer. These disruptions in permeability are particularly effective at influencing lateral movement of groundwater in the gently sloping landscape of the study area.

The Wilshire fen (Figure 2) illustrates permeability reduction across the pumice/alluvium contact. A map of the Wilshire fen is presented in Figure 3. The western edge of the fen is bounded by an ephemeral stream valley

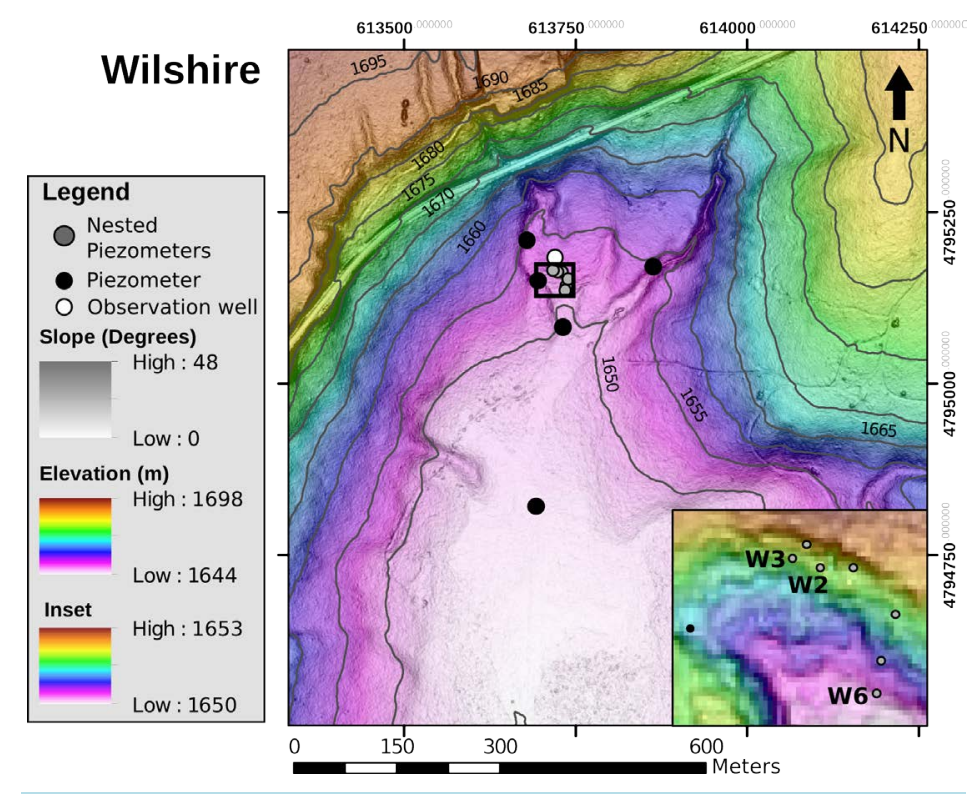

Figure 3. Digital elevation model for Wilshire fen constructed from LiDAR. The black box shows the location of the nested piezometers installed by The Nature Conservancy and the US Forest Service. The inset map shows the distribution of nested piezometers within the fen. The numbered nested piezometers are discussed elsewhere in this paper. 
that has cut through the pumice deposit to the pre-eruption surface in its upper reach but only partially through the pumice deposit in its lower reach (87 $\mathrm{cm}$ of lower pumice remaining).

On the right side of the photograph in Figure 4 peat overlies pumice and the water table was at the surface on 19-April-2014. Fresh mounds of soil near the center of the photograph indicate the water table was deep enough for rodents to colonize alluvium that underlies the left side of the photograph. Farther up valley from the site shown in Figure 4 on the west side of the valley and opposite the fen, $3 \mathrm{~cm}$-high fountains of groundwater were observed discharging from pumice during the WY12 freshet where the lateral continuity within the pumice deposit was impeded by alluvium.

Lateral disruption of the physical properties of the pumice aquifer are also produced by iron cementation in the pumice deposit or at the contact between alluvium and pumice. Figure 5 illustrates this relation at the Johnson fen (Figure 6) where a fen discharges from the north side of the stream valley (left side of photograph). Seepage from the fen feeds a perennial creek (low discharge) at the base of the slope. An auger hole drilled in the forest on the south side (right side in photograph) encountered pumice and overlying alluvium strongly cemented by reddish/brown iron oxide. Iron oxide may occur as cement between grains, as replacement of pumice, or both. In some places, iron cementation impeded progress of the hand auger and rebar was needed to break through the zone of cementation.

Peat deposits up to $1.4 \mathrm{~m}$ thick underlie the sloping surfaces of fens. Resistance to probing with a rod (wooden dowel or steel rod) increases within 20 to $30 \mathrm{~cm}$ of the surface. Near the contact with the underlying pumice deposit interaction between pumice admixed in the peat and the rod produces a scratchy sound. This is also associated with a change in the pressure needed to advance the rod to greater depth. The peat deposits overlie the erosion surface that cuts downward through the internal stratigraphy of the pumice deposit. In general, the peat is saturated throughout the growing season (see below). The water table in piezometers screened within the peat deposits was usually near the local ground surface. In early spring the piezometric surface may be a few $\mathrm{cm}$ above the local ground surface and water flows as a thin $(2-3 \mathrm{~cm})$ layer across the surface of the fen. Such sheet flow was particularly well illustrated at Crooked Meadow fen in WY11 and WY12. The piezometric surfaces for the underlying pumice aquifer may be up to $25 \mathrm{~cm}$ above the local ground surface. In late summer, the water table measured in piezometers completed in the pumice aquifer may be 10 to $20 \mathrm{~cm}$ below the local ground surface, but the peat is saturated throughout and water is ponded at the surface.

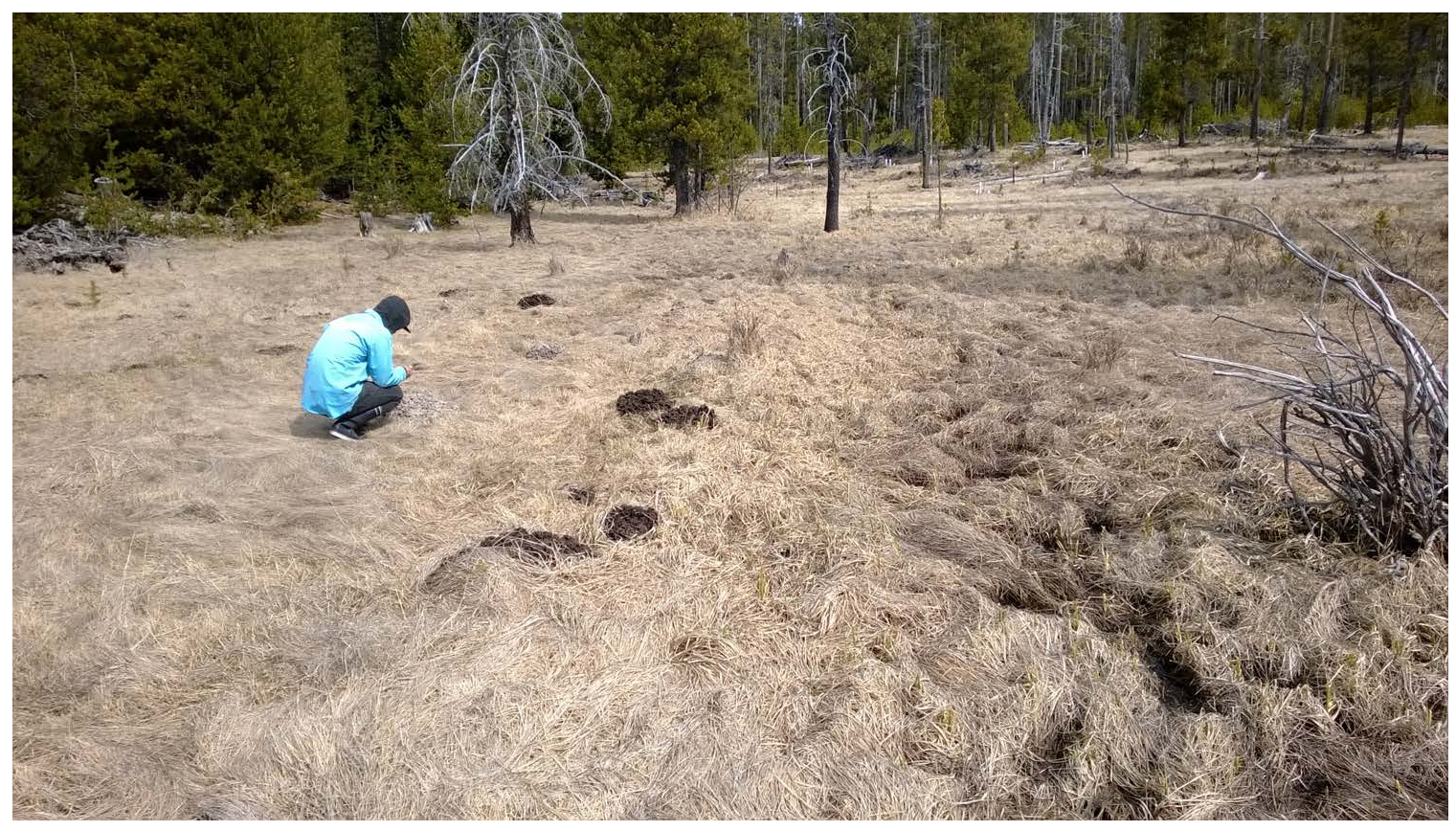

Figure 4. Wilshire fen (distance) on 20-April-2014 showing mounds produced by burrowing rodents where alluvium was the near-surface substrate (left side of photograph) and no burrows where saturated peat overlying pumice was the near-surface substrate (right side of photograph). The white pipes on the distant slope are the nested piezometers installed by The Nature Conservancy and US Forest Service for study of the Wilshire fen. 


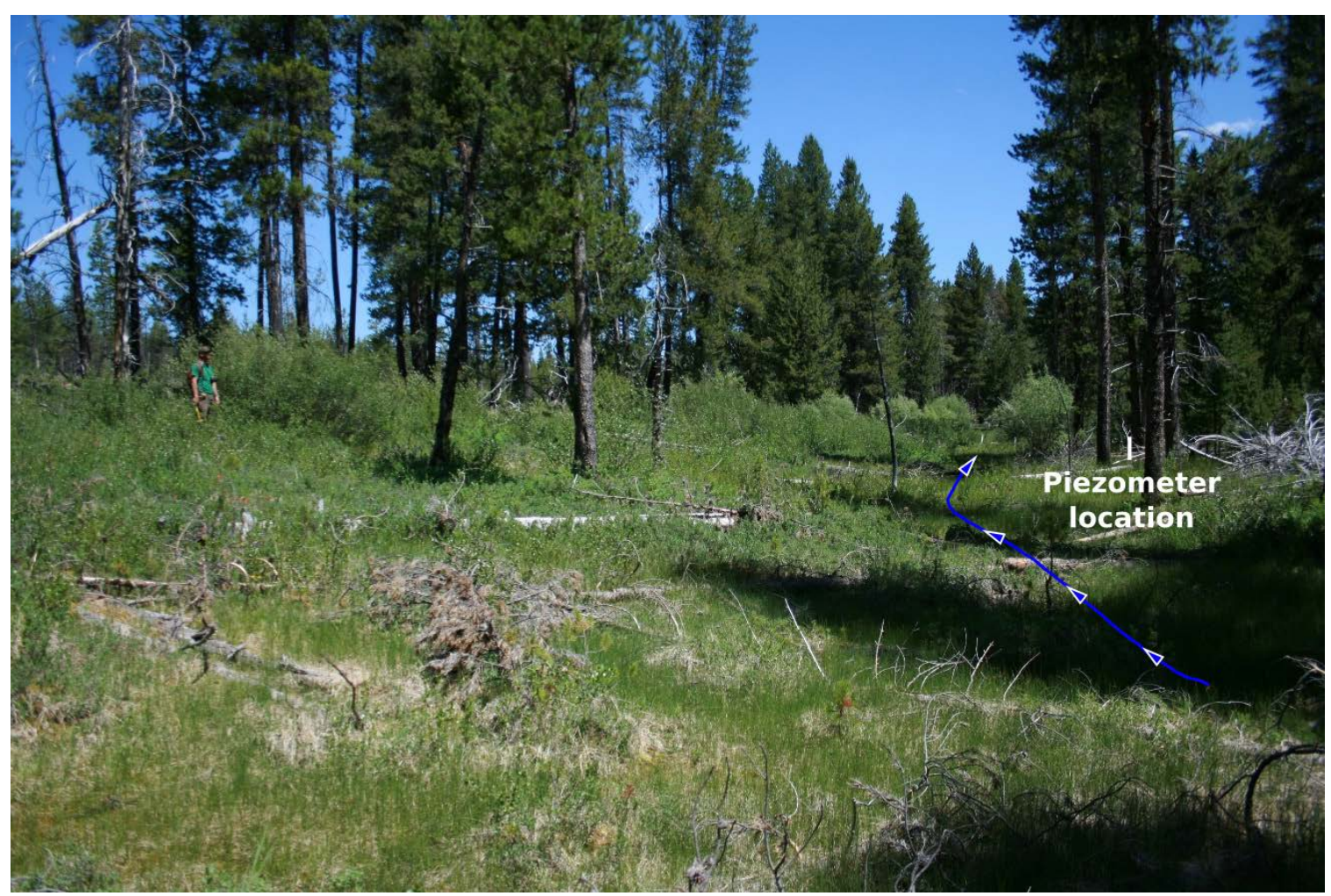

Figure 5. Fen discharging from slope on left side of photograph. Bog birch is common near where the person is standing. Bog blueberry is low shrub down slope. Slope is underlain by peat. A perennial stream hugs the right side of the valley (indicated by arrows). An auger hole near the right edge of the photo intersected strong iron cementation in pumice and alluvium.

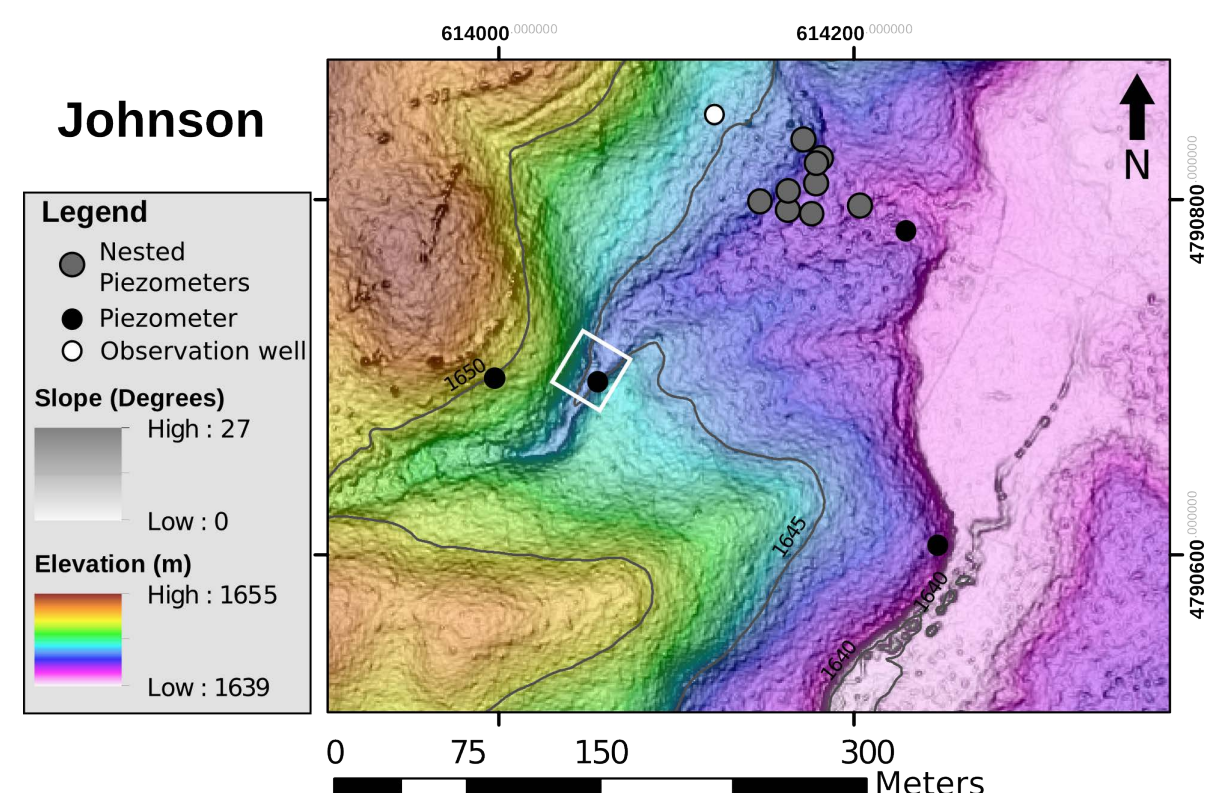

Figure 6. Digital elevation model for Johnson fen. Johnson Meadow, the low elevation area on the right side of the map is underlain by alluvium. Where the channel is present at the south end of the meadow olivine basalt flows are exposed where the valley narrows. The nested piezometers installed by The Nature Conservancy and US Forest Service are shown as gray circles. The white circle is the location of three monitoring wells. The white box shows the location of the fen in Figure 5. The slope break between the meadow and higher elevations to the west is characterized by groundwater seepage that supports bog blueberry, bryophytes, and locally pitcher plants. 


\subsection{Bedrock and Regolith}

The pre-eruption landscape was underlain by bedrock units including volcaniclastic sedimentary rocks, basaltic hydrovolcanic deposits, welded and non-welded pyroclastic flows, and olivine basalt lava flows. The bedrock units graded upward into regolith and were locally overlain by alluvium.

Bedrock geology is known from sparse outcrops of resistant olivine basalt and basaltic andesite lava flows exposed through the pumice blanket and from shallow monitoring wells $(\sim 30 \mathrm{~m})$ installed at four sites [13]. Although outcrops are dominated by lava flows, drill cores indicate poorly sorted volcaniclastic sedimentary rocks, non-welded pyroclastic flows, and basaltic hydrovolcanic deposits are abundant and locally contribute the greater thickness of deposits in drill cores. Based on similar stratigraphic relations south of the study area where age determinations are available (Cummings, unpublished data), the age of section is believed to be latest Miocene to Pleistocene.

Accumulation of bedrock units was in two phases separated by a time during which erosion was dominant. During phase 1 basaltic tuff cones, poorly sorted volcaniclastic sedimentary rocks, non-welded pyroclastic flows and olivine basalt lava flows were deposited between larger basaltic andesite volcanic centers that formed the main topographic features of the landscape. Basaltic shield volcanoes (olivine basalt to basaltic andesite) erupted near the end of this phase. Phase 1 was followed by a time when erosion exceeded the rate of accumulation. At this time, erosion exhumed earlier deposited basalt flows producing lava capped plateaus. Valley floors were cut into the relatively soft volcaniclastic sedimentary and volcanic rocks interlayered with the lava flows. The valley of Jack Creek, the main stream in the study area, and its tributary valleys were formed at this time. The amount of incision is estimated at about $80 \mathrm{~m}$ (e.g. capping lava at Skookum Butte to floor of Jack Creek).

The stratigraphy and lithology of phase 1 units are known from sparse outcrops and drill cores recovered from monitoring wells drilled at the Dry Meadow, Wilshire, and Johnson fens and in section 5 (T. 27 S. R. 10. E.) (Figure 2). At the three fen sites the deepest of three wells was cored to $27.3 \mathrm{~m}$ at Dry Meadow, $28.9 \mathrm{~m}$ at Johnson fen, and $31.8 \mathrm{~m}$ at Wilshire fen below local ground surface. In section 5, the solitary well was cored to $15.2 \mathrm{~m}$. At the fen sites, the monitoring wells were placed at 1 to $2 \mathrm{~m}$ above the elevation of groundwater discharge in the fen. Photographs of the cores, core logs, and depth to water table in each well (10 total) are reported by Gusey [13]. At Johnson and Wilshire fens and section 5, the regolith and bedrock units first encountered were weathered, poorly sorted, volcaniclastic sedimentary rocks (section 5 and Johnson fen) and nonwelded pyroclastic flows (Wilshire fen). In section 5, the sedimentary section immediately below the pumice deposit was silt-rich (12\% to $68 \%)$ sand (20\% - 58\%) with admixed, matrix-supported, sub-angular to sub-rounded pebbles (4\% - 44\%). The permeability coefficient, $\mathrm{k}$, had values between $0.01 \mathrm{~cm} / \mathrm{s}$ and $0.08 \mathrm{~cm} / \mathrm{s}$. At Dry Meadow, the first rocks encountered were weathered, once glassy, basalt tuff breccia. The bedrock at Dry Meadow appears to have been deposited during phase 2 based on topography and lithology.

Phase 2 was characterized by faulting and the eruption of low volume olivine basalt lava flows, cinder cones, and vent complexes. Northwest alignment of vents suggests volcanism and faulting were coeval. The phase 2 olivine basalt flows are generally thin (3 to $5 \mathrm{~m}$ ) and form intracanyon flows where they flowed into the Jack Creek valley. Locally, a flow(s) blocked the ancestral Jack Creek valley and forced relocation of the stream along the western margin of the flow. The Johnson fen and associated wetlands are believed to be controlled by the unconformity that lies between fine-grained regolith and bedrock units of phase 1 and the olivine basalt lava flow that erupted into the valley in phase 2 (Figure 7).

During both phase 1 and 2 valley systems with somewhat coarser grained deposits appear to have formed by normal surface processes. During both phase 1 and 2 these coarser-grained deposits were locally buried by thin basalt lava flows. The permeable zones formed during phase 1 were exhumed during the time when erosion was dominant. Unconformities between phase 2 lava flows and the erosion surface cut into rocks of phase 1 produced a younger generation of contact-related permeable zones. Based on geomorphology of lava flows, the slope of the land during phase 1 appears to have been gentle to the south. During the period of erosion the slope persisted to the south. Phase 2 lava flows also have the tendency to align with a southern slope. The eruption of phase 2 olivine basalt predates faulting and uplift of Walker Rim.

\subsection{Sources of Groundwater}

Three types of flow paths have been identified as the source of the groundwater that discharges at the fens. The 


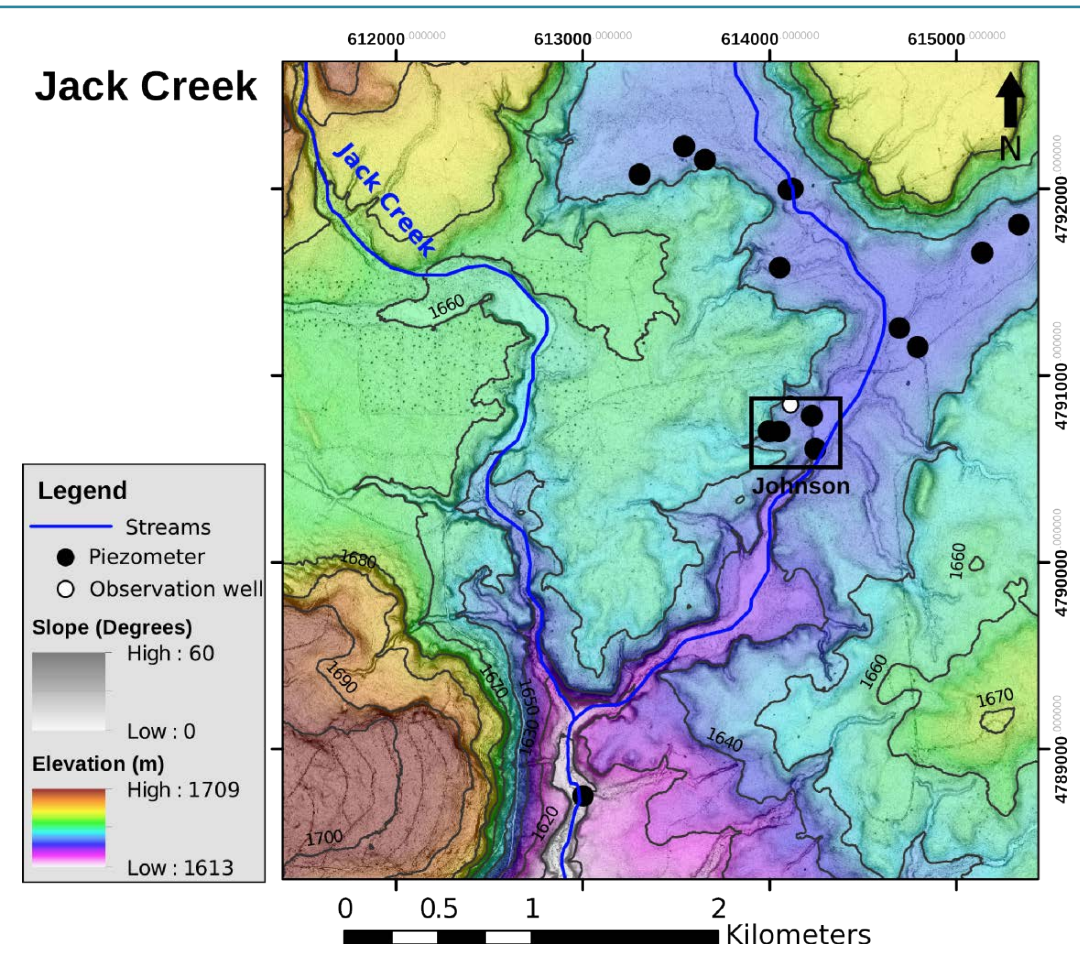

Figure 7. The location of the Johnson fen in relation to Jack Creek. The area between the fen and Jack Creek is underlain by an olivine basalt lava flow erupted during phase 2 onto an eroded surface cut into low permeability rocks of phase 1.

predominant flow path lies within the pumice deposit as a perched unconfined aquifer. The water source is snow melt that infiltrates into the unconfined pumice aquifer during the freshet. The second type of flow path is characterized by shallow circulating, snow-melt derived groundwater that migrates along permeable zones as described in the section on bedrock. The third type of pathway is controlled by faults and allows deeper seated, chemically distinct groundwater to rise to the surface. These pathway types have been defined through four separate approaches: 1) response of water levels in fens to precipitation in WY10 through WY14, 2) comparing water temperature data in fens to a reference site, 3) comparing electrical conductivity and oxidation/reduction potential among sites, and 4) distribution of groundwater in monitoring wells at Wilshire, Johnson, and Dry Meadow fens and in section 5 (T. 27 S., R. 10 E.).

\subsubsection{Response of the Water Levels in Fens to Precipitation}

The depths to water table below local ground surface (bgs) measured in piezometers screened in the peat layer and completed in the pumice aquifer at the Johnson, Wilshire, Dry Meadow, Round Meadow, Jack Creek at Skookum Butte, FSLR 460, and Crooked Meadow fens (Figure 2) were compared to non-fen settings and to the precipitation records at the Chemult Alternate SNOTEL Site (Station 395) [14]. The SNOTEL site is located at an elevation of $1478 \mathrm{~m}$ while the fens are located at elevations greater than $1585 \mathrm{~m}$. Water level data are available at the fen sites for WY10 through WY14. Records for the Chemult Alternate SNOTEL Site are available since 1981 [14]. The annual precipitation cycle during the water year is illustrated in Figure 8 which is the 30 year average for the SNOTEL site. The 30-year average precipitation for the SNOTEL site is $69.8 \mathrm{~cm}$. Of the five water years, WY11 and WY12 were above the 30-year average $(82.5 \mathrm{~cm}$ and $71.9 \mathrm{~cm}$, respectively) and WY10, WY 13, and WY14 were below average $(60.2 \mathrm{~cm}, 62.0 \mathrm{~cm}$, and $46.7 \mathrm{~cm}$, respectively). WY 14 was the fourth driest in the 30-year record.

In addition to fen sites, auger holes converted to piezometers screened in the pumice aquifer were installed in a variety of wetland environments in the study area [15]. These piezometers provide insight into the response of the water table to the precipitation input for WY10 through WY14. Figure 9 contains the hydrograph for a piezometer in section 5 (T. 27 S., R. 10 E.; Figure 2), a non-fen setting. The records for WY11 through WY14 include measurements on June 1 of each year. In WY11 and WY12, particularly in WY11, the June 1 observation 


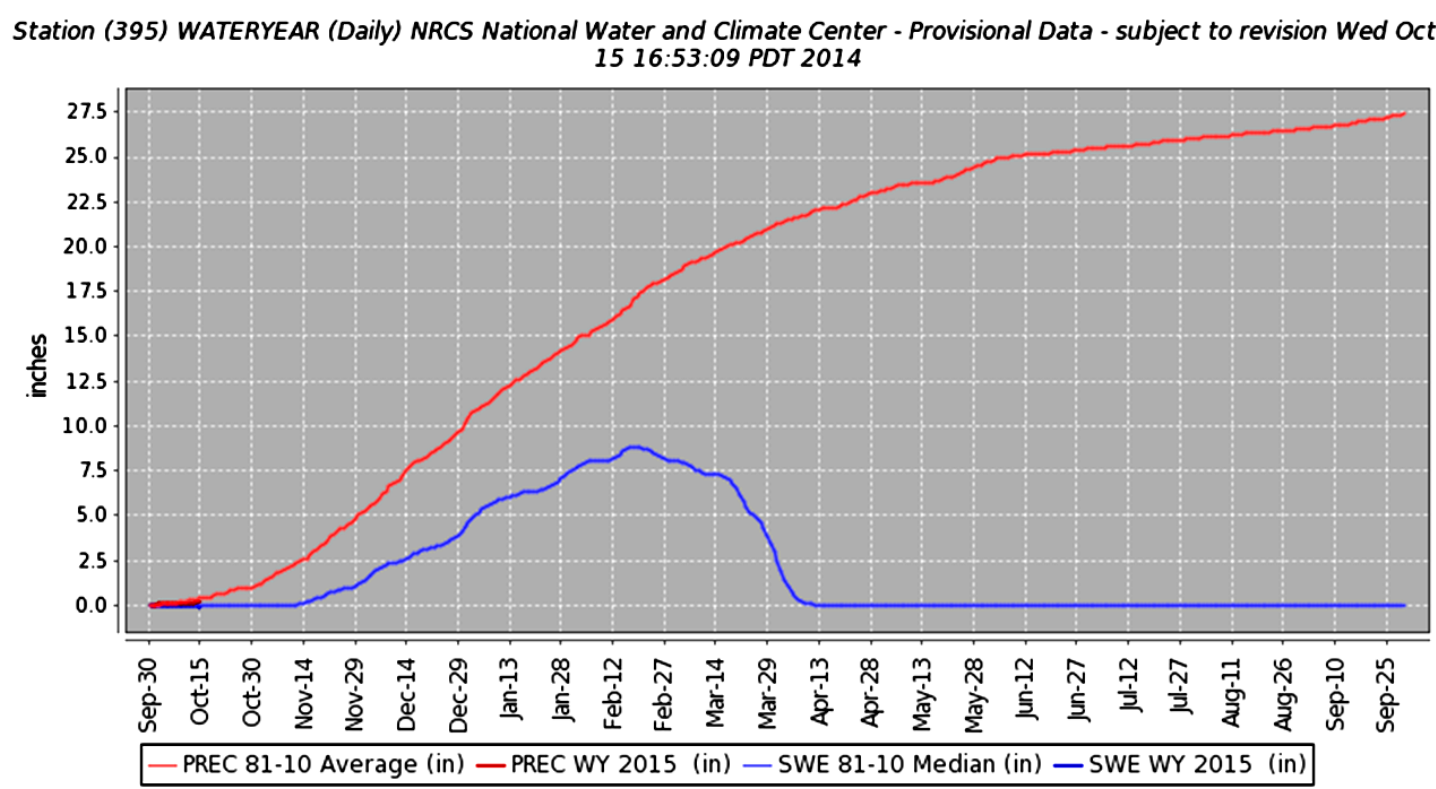

Figure 8. Average precipitation and snow water equivalent for 30 years at the Chemult Alternative SNOTEL station 395 [14].

\section{Section 5 westernmost piezometer FSLR 601}

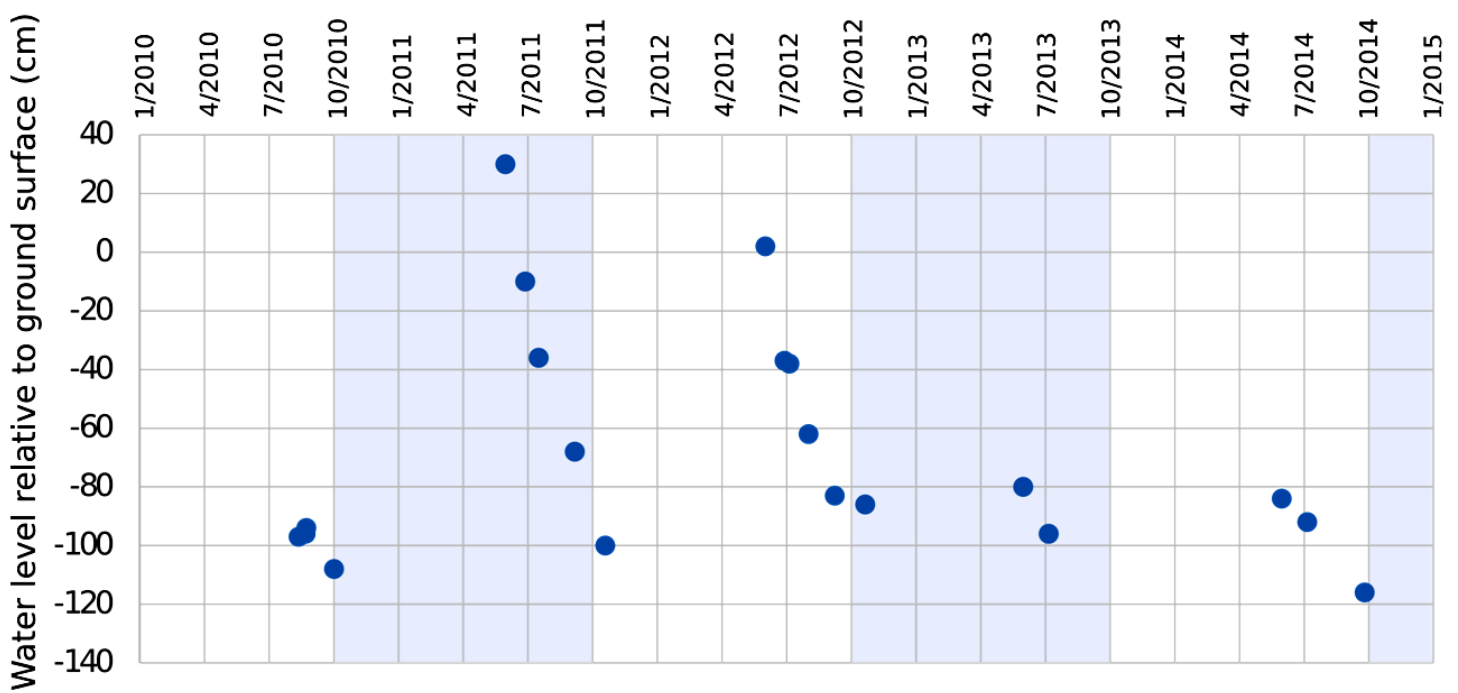

Figure 9. Depth to water table below local ground surface in a non-fen setting. Site is located in the section 5, T. 27 S., R. 10 E. (Figure 2) groundwater system. The thickness of the pumice deposit at this site was approximately $150 \mathrm{~cm}$ thick suggesting that most of the upper pumice unit had been eroded. FSLR = forest service local road.

found the ground surface at the piezometer and the surrounding lodgepole pine forest inundated. In WY13 and WY14 the June 1 observations indicated recharge of the pumice aquifer was not sufficient to raise the water table to within $80 \mathrm{~cm}$ of the local ground surface. The record for the piezometer presented in Figure 9 was characteristic of non-fen wetland environments throughout the Walker Rim study area. Water level data for nested piezometers in the fens completed in the pumice aquifer show similar, but less dramatic, water table fluctuations with annual precipitation as do piezometers not associated with fens.

The Nature Conservancy in cooperation with the US Forest Service installed nested piezometers in three fens (Johnson, Wilshire, and Dry Meadow, Figure 2) to assess the volume of water that could be extracted from these fens during the growing season for watering cattle without harming the groundwater-dependent ecosys- 
tems they support [4]. At the Johnson, Wilshire, and Dry Meadow fen sites, the nested piezometers were driven into the peat and pumice. One piezometer (WT) was driven into the peat and screened over the first $0.9 \mathrm{~m}$. In some cases, the piezometer was driven too deeply and crossed the peat/pumice contact. The piezometers in the pumice aquifer were open ended and driven to different depths ( 1.0 m and $1.4 \mathrm{~m})$. Deeper piezometers hit refusal, particularly at Dry Meadow [4]. Many of the measured depths of piezometers in the pumice aquifer are consistent with the depths reported by Aldous and Gurrieri [4], however, in some cases recent measurements show differences of up to $70 \mathrm{~cm}$.

The water table relative to local ground surface for three clusters consisting of 3 piezometers each at Wilshire fen are plotted in Figures 10-12. These clusters were selected to illustrate the change in head in the pumice aquifer over time. Piezometer clusters W2 and W3 are both near the highest elevation where diffuse discharge from the peat is present. In these two clusters the WT piezometer was completed in peat and did not break through the peat/pumice contact [4]. Piezometer cluster W3 was selected because electrical conductivity in piezometer W3-1.4 with reported completion depth of $1.4 \mathrm{~m}$ bgs [4], but with measured depth of $69 \mathrm{~cm}$ bgs (2-June-2012) was anomalously high. Piezometer nest W6 was at the lowest elevation near the toe of the fen.

Nested piezometers in cluster W2 (Figure 10, Figure 3, inset) illustrate water levels in the upper tier of nested piezometers (W1, W2, W3, and W5). The W2-WT piezometer was screened in peat (73 cm thick, [4]) and the W2-1.0 and W2-1.4 piezometers were open ended in the pumice aquifer. The piezometric surface for the W2-WT piezometer was up to $12 \mathrm{~cm}$ above ground surface on June 1 each water year. However, in WY13 and WY14 the water table was below ground surface by up to $32 \mathrm{~cm}$ at the end of the water year. For the W2-1.0 and W2-1.4 piezometers, completed in the pumice aquifer, the June 1 measurements were roughly $20 \mathrm{~cm}$ above the local ground surface and approximately $1 \mathrm{~m}$ above the contact between the pumice and overlying peat. Artesian flow would issue from the pumice aquifer if not constrained by the piezometer. At some fens naturally occurring artesian flow from the pumice aquifer produces streams that flow across the surface of the peat layer (e.g. Johnson, 460 fen, Round Meadow fen, Jack Creek fen at Skookum Butte, Figure 2). During WY13 and WY14 the water table in W2-1.0 and W2-1.4 declined to 20 to $30 \mathrm{~cm}$ below local ground surface. The 25-September-2014 measurement recorded the water table at approximately the same depth below ground surface in all three piezometers.

Nested piezometers in cluster W3 are also part of the higher elevation sites, but the cluster was farthest west and near the contact with the alluvium of the western bounding ephemeral stream valley (Figure 3, inset). Peat

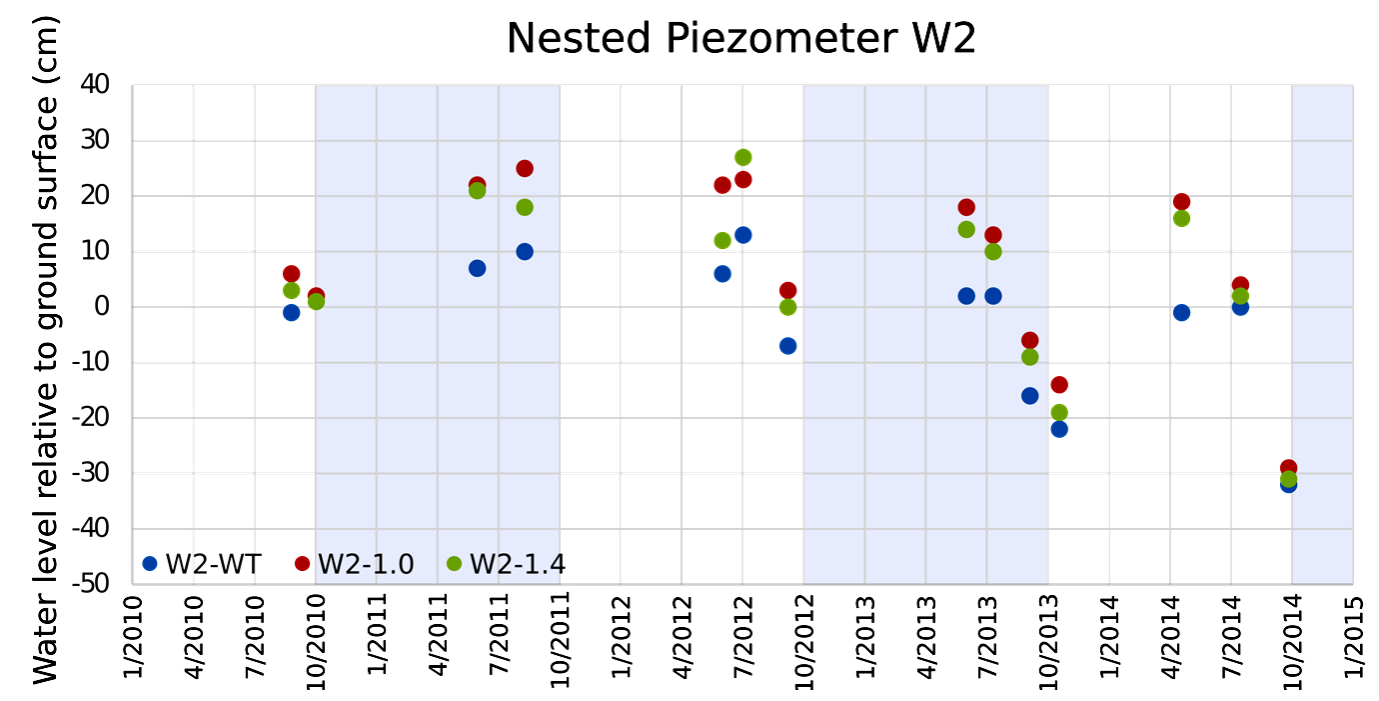

Figure 10. Water levels measured in the W2 piezometer cluster at Wilshire fen. The patterns observed in the W2 piezometer cluster are similar to those observed in the W1 and W5 clusters. The depth of the W2-WT piezometer was measured at $105 \mathrm{~cm}$ bgs on 2-June-2012 and had $95 \mathrm{~cm}$ of screen in peat. The depth of W2-1.0, an open-ended piezometer, was measured at $86 \mathrm{~cm}$ bgs on 2-June-2012. The depth of W2-1.4, an open-ended piezometer, was measured at $144 \mathrm{~cm}$ bgs on 2-June-2012. 


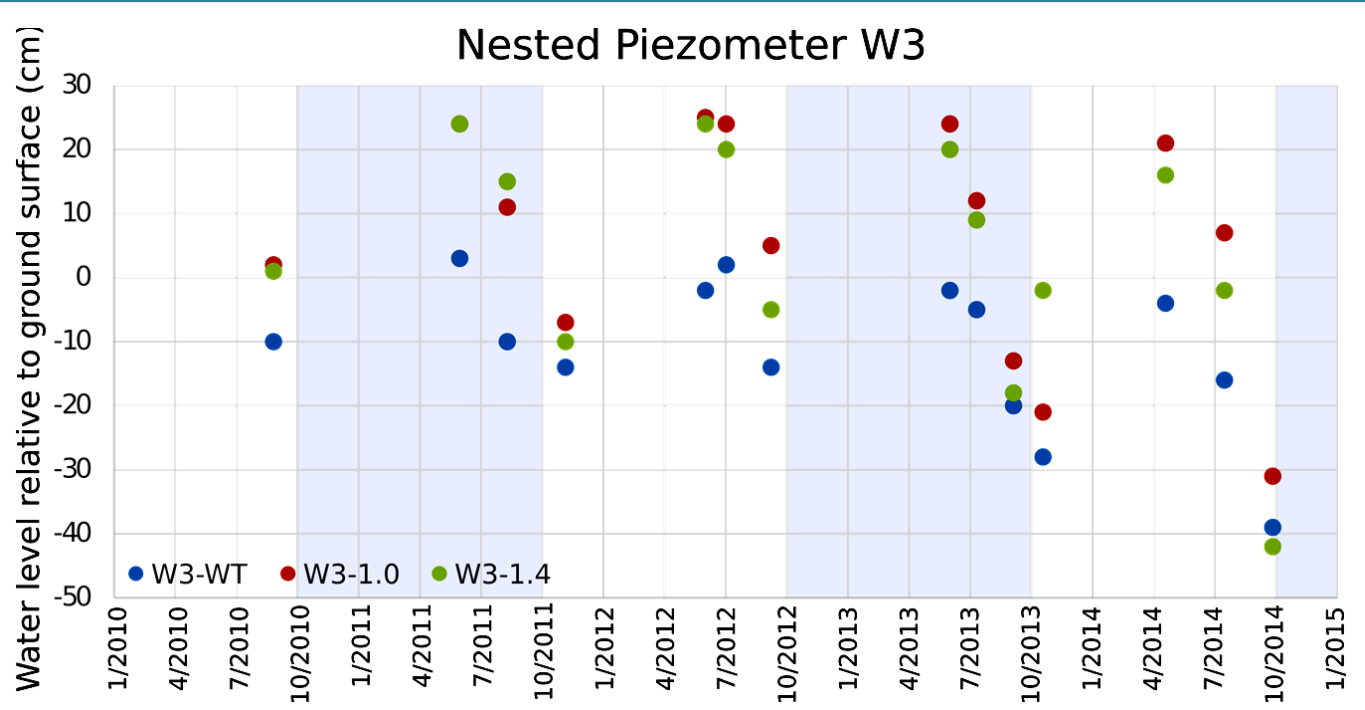

Figure 11. Water levels measured in the W3 piezometer cluster at Wilshire fen. Electrical conductivity in the W3-1.4 piezometer was commonly as high as $280 \mu \mathrm{S} / \mathrm{cm}$. The W3-WT piezometer was screened in peat (95 cm screen) and had a bottom depth of $108 \mathrm{~cm}$ on 2-June-2012. The W3-1.0 piezometer was an openended piezometer with depth reported [4] at $100 \mathrm{~cm}$ bgs, however, depth was measured as $57 \mathrm{~cm}$ bgs on 2-June-2012. The W3-1.4 piezometer was an open-ended piezometer with depth reported [4] at $140 \mathrm{~cm}$ bgs, however, depth was measured at $69 \mathrm{~cm}$ bgs on 2-June-2012. Electrical conductivity in the W3-1.4 piezometer is consistently 8 to 10 times higher than all other piezometers (except W3-1.0) at the Wilshire fen.

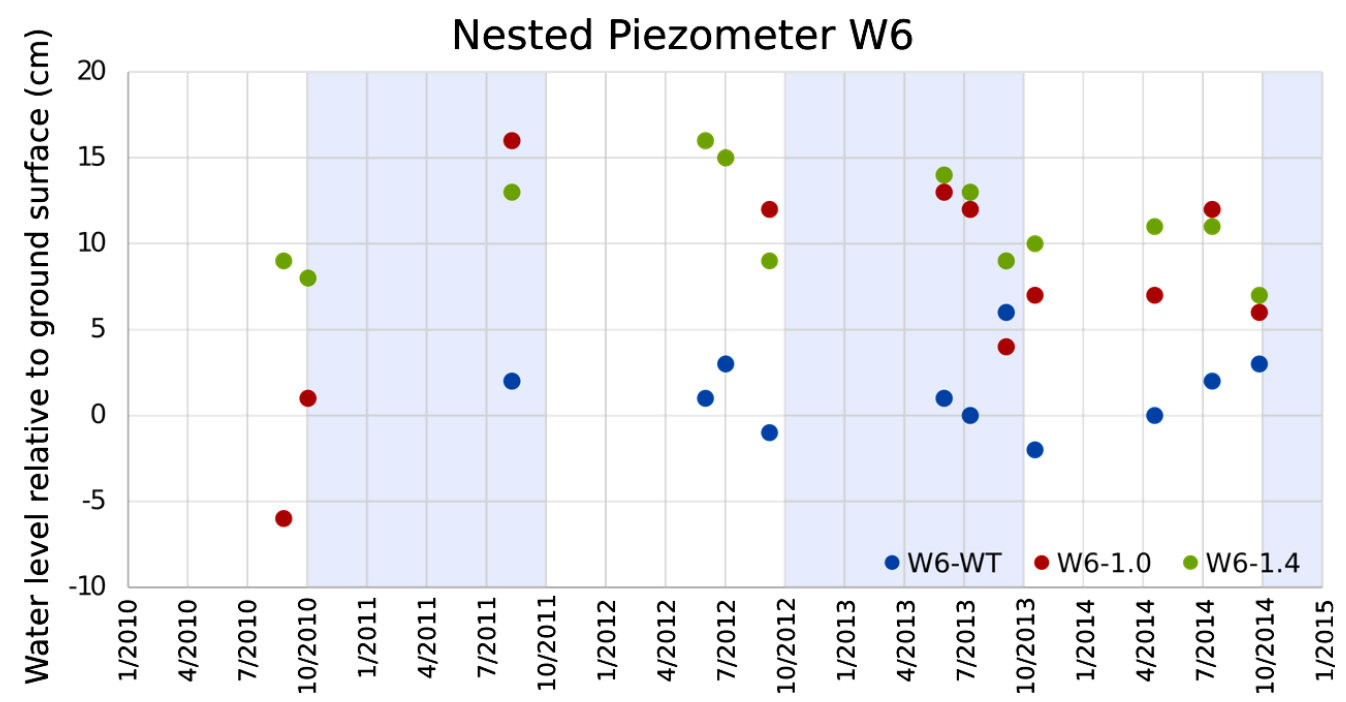

Figure 12. Water levels measured in the W6 piezometer cluster at Wilshire fen. Depth of the W6-WT piezometer was measured at $102 \mathrm{~cm}$ on 2-June-2012 (reported at $105 \mathrm{~cm} \mathrm{[4]).} \mathrm{The} \mathrm{piezometer} \mathrm{was} \mathrm{screened} \mathrm{to} 95$ $\mathrm{cm}$ in peat. The W6-1.0 piezometers was measured at $104 \mathrm{~cm}$ bgs on 2-June-2012 (reported depth of $112 \mathrm{~cm}$ [4]). The W6-1.4 piezometer was measured at $144 \mathrm{~cm}$ bgs on 2-June-2012 (reported depth of $141 \mathrm{~cm}$ [4]).

thickness was reported as $61 \mathrm{~cm}$ at this cluster [4]. The depth of the W3-WT piezometer was measured at 108 cm bgs, but the depths measured at the W3-1.0 and W3-1.4 were less (57 cm and $69 \mathrm{~cm}$, respectively, 2 June 2012), considerably less than reported by Aldous and Gurrieri [4] (100 cm and $140 \mathrm{~cm}$, respectively). The water levels measured in the W3 cluster are shown in Figure 11. Water levels in the W3-WT piezometer, completed in peat, was near surface in the early growing season and as much as $39 \mathrm{~cm}$ bgs at the end of the WY14. Water levels in the W3-1.0 and W3-1.4 piezometers completed in the pumice aquifer display similar behavior to other piezometers at similar elevation. Although similar in water levels, the W3-1.4 piezometer stands out because of consistently anomalous electrical conductivity compared to all other piezometers at Wilshire fen. Electrical 
conductivity in piezometers completed in the pumice aquifer at Wilshire fen was $\sim 25$ to $40 \mu \mathrm{S} / \mathrm{cm}$, however, electrical conductivity as high as $263 \mu \mathrm{S} / \mathrm{cm}$ have been recorded (higher values in late spring) in the W3-1.4 piezometer. The electrical conductivity decreased in late summer $(\sim 150 \mu \mathrm{S} / \mathrm{cm})$. When higher values were present in spring and early summer, electrical conductivity was also elevated in piezometer W3-1.0 (separation distance $=50 \mathrm{~cm}$ ). Iron staining on the exterior of the W3-1.4 piezometer was consistent with oxidation-reduction potential values that ranged from $-40 \mathrm{mV}$ to $130 \mathrm{mV}$. Iron concentrations of $20.4 \mathrm{mg} / \mathrm{l}$ were measured in early November 2012.

Nested piezometers in cluster W6 are at the lowest elevation in the Wilshire fen (Figure 3, inset). At this site Aldous and Gurrieri [4] report peat thickness of $119 \mathrm{~cm}$, the greatest thickness at the Wilshire fen. The piezometric surface for the W6-WT piezometer was within a few $\mathrm{cm}$ of the local ground surface (above and below) each measurement (Figure 12). Likewise, the piezometric surface for the W6-1.0 and W6-1.4 piezometers was persistently above the local ground surface. At the end of WY14 these piezometers and the piezometers completed in the pumice aquifer in the W4 cluster at mid slope were the only ones where the piezometric surface was above the local ground surface. The electrical conductivity in the W6-1.4 piezometer was often about 10 to 15 $\mu \mathrm{S} / \mathrm{cm}$ higher than piezometers in the W1, W2, W4, and W5 clusters.

The three clusters of nested piezometers at Wilshire fen were consistent with the water level behavior in the other fens monitored in this study. The water table in the WT piezometers at all sites was commonly within a few $\mathrm{cm}$ of the local ground surface, except in WY14 when late summer values in the W2 and W3 piezometer clusters were approximately $30 \mathrm{~cm}$ below the local ground surface. Most of the WT piezometers were screened in the peat layer. The piezometers completed in the pumice aquifer (1.0 and 1.4) indicate the piezometric surface was above local ground surface throughout WY11 and WY12, but fell below the local ground surface in late summer in WY13 and particularly WY14. Similar patterns were observed at other fen sites. However, two sites, the "mystery hole" at Round Meadow and parts of the FSLR 460 fen experienced greater decline in water table as WY14 progressed. At the "mystery hole", a vertical natural hole through the peat layer produced by piping, water table at $85 \mathrm{~cm}$ below local ground surface was recorded on 18-September-2014. In WY11 and WY12 artesian flow was taking place throughout the water year at this site. At the 460 fen, an elk wallow in peat experienced severe desiccation cracking (approximately $30 \mathrm{~cm}$ deep) by 17-July-2014. Figure 13 illustrates the extent of these cracks. The peat layer near this site is approximately $90 \mathrm{~cm}$ thick (estimated by pushing steel rod into peat deposit).

The location of the wallow with desiccation cracks shown in Figure 13 is shown in the digital elevation model in Figure 14. Also shown in this figure are the locations of a second elk wallow, a stream flowing from a

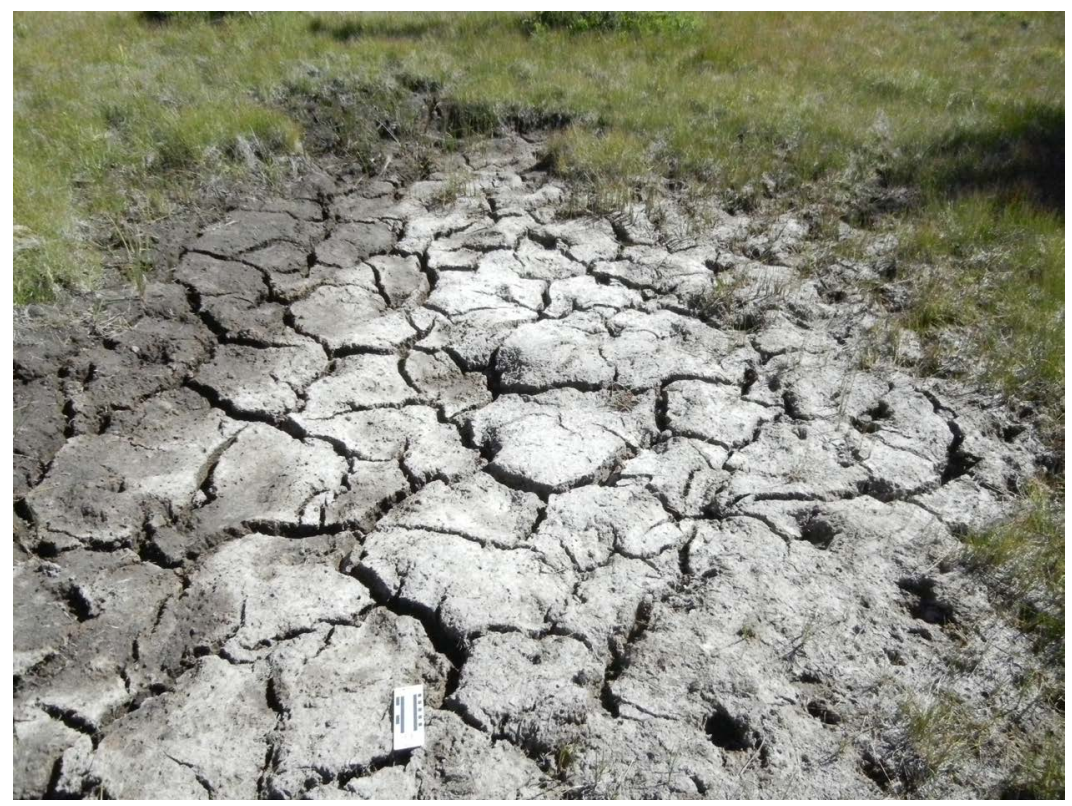

Figure 13. Desiccation cracks in peat at the 460 fen on 17-July-2014. Cracks are up to $30 \mathrm{~cm}$ deep. 


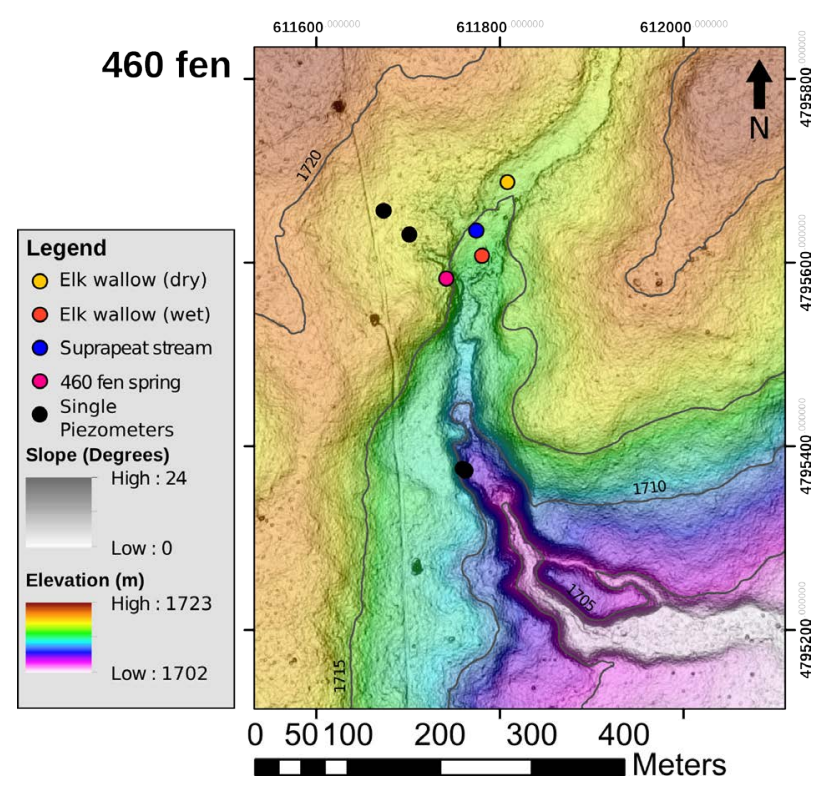

Figure 14. Digital elevation model for the 460 fen. The fen slopes from the northwest to southeast across the valley where the elk wallows are located. Olivine basalt crops out at the slope break south of the 460 fen spring and defines the southern boundary of the upper fen. The southern piezometers are located in a smaller fen area. The northeast side of this lower fen area is underlain by sub-rounded boulders of olivine basalt where pumice has been eroded away.

discharge point in the peat, and a spring at the edge of the fen that maintained water at the surface throughout WY14. An abrupt boundary was noted between the two elk wallows on 17-July-2014 that demarked areas where vegetation was wilted and desiccation cracks were present in the elk wallow from areas where vegetation was not wilted and the spring, stream, and the second elk wallow maintained water at the surface. The four piezometers at this site also contained water throughout WY14. The distribution of water in the surface and subsurface environments suggests the 460 fen received at least some water from a permeable zone at the base of olivine basalt flows that erupted from a shield volcano located north of the fen. In WY12 and WY13 when more water was present in the system the drying noted in WY14 did not occur in the northern part of the fen.

\subsubsection{Water Levels in Monitoring Wells}

In addition to nested piezometers within areas of fen discharge, three monitoring wells were drilled upslope from the fen at the Johnson, Wilshire, and Dry Meadow fens (Figure 2). In each case, the monitoring wells were drilled where topography suggested the entire pumice section was present and there was no indication of groundwater discharge. At each site, the three closely spaced wells were drilled to determine bedrock geology and the distribution of groundwater. Zones of fracture permeability were of interest because such fractures could provide pathways by which deeper seated groundwater could reach the near-surface environment and provide discharge to the fens.

At all three fen sites, the deepest wells, completed at approximately $30 \mathrm{~m}$ bgs were dry (fractured olivine basalt at Wilshire and Johnson fens; coarse $(\sim 8 \mathrm{~cm})$, open-textured basalt breccia at Dry Meadow). The screened interval was placed near the bottom of each of these deep wells. The intermediate wells were drilled to depths of between 14 and $18 \mathrm{~m}$ bgs and contained perched aquifers, but water in each well was only a few centimeters deep. The shallow wells penetrated approximately $250 \mathrm{~cm}$ of pumice before entering the regolith. The static water table in the shallow wells was $113 \mathrm{~cm}$ at Dry Meadow fen, $131 \mathrm{~cm}$ at Johnson fen, and $143 \mathrm{~cm}$ at Wilshire fen on 10-October-2010 [13]. At the end of WY14 the water table was $144 \mathrm{~cm}$ at Dry Meadow fen, $168 \mathrm{~cm}$ at Johnson fen, and $177 \mathrm{~cm}$ at Wilshire fen (25-September-2014). The fluctuations in water level in the monitoring wells during WY10 through WY14 are similar to those in the nested piezometers at each fen site. The greatest declines were measured at the end of WY14 when water levels were estimated 30 to $35 \mathrm{~cm}$ below June levels. In all cases, groundwater was perched in the unconfined pumice aquifer. 


\subsubsection{Water Temperature}

In 2010 temperature and relative humidity probes were installed near the Johnson fen in a stand of lodgepole pine which provided mottled shade. Two probes were installed at 50 and $95 \mathrm{~cm}$ bgs, respectively, and one at approximately $1.8 \mathrm{~m}$ above ground surface. A piezometer screened in the pumice aquifer was also installed to a depth of $180 \mathrm{~cm}$ bgs. The temperature and relative humidity between 26-April and 19-October-2013 for subsurface probes are shown in Figure 15(a) and Figure 15(b). The data presented in Figure 15(a) and Figure 15(b) provided an indication of temperatures expected within one meter of the ground surface for all dates in this time span. These expected temperatures were compared to dates, measured temperatures, and depths in fen and non-fen piezometers. Temperatures higher than those recorded at the instrument site for a specified date and depth were expected where sites were in direct sunlight. Temperatures lower for a specified date and depth than those recorded at the instrument site were expected where cooler water at deeper levels in the aquifer $(>1 \mathrm{~m})$ was rising to the surface or a deeper groundwater source from an aquifer in the bedrock section was discharging into the pumice aquifer.

Figure 16 illustrates the depth-temperature relations measured on 12-July-2013 in piezometers completed in

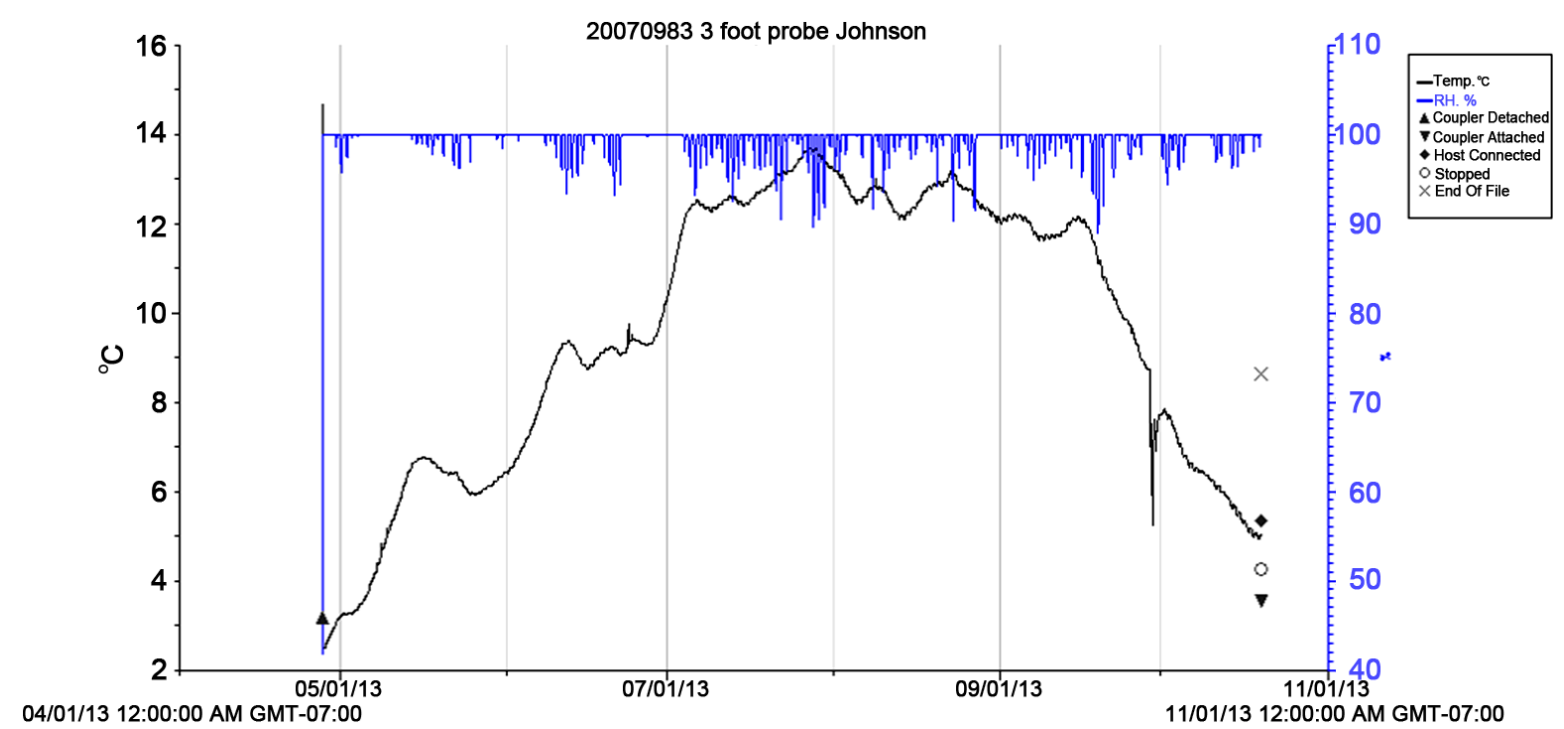

(a)

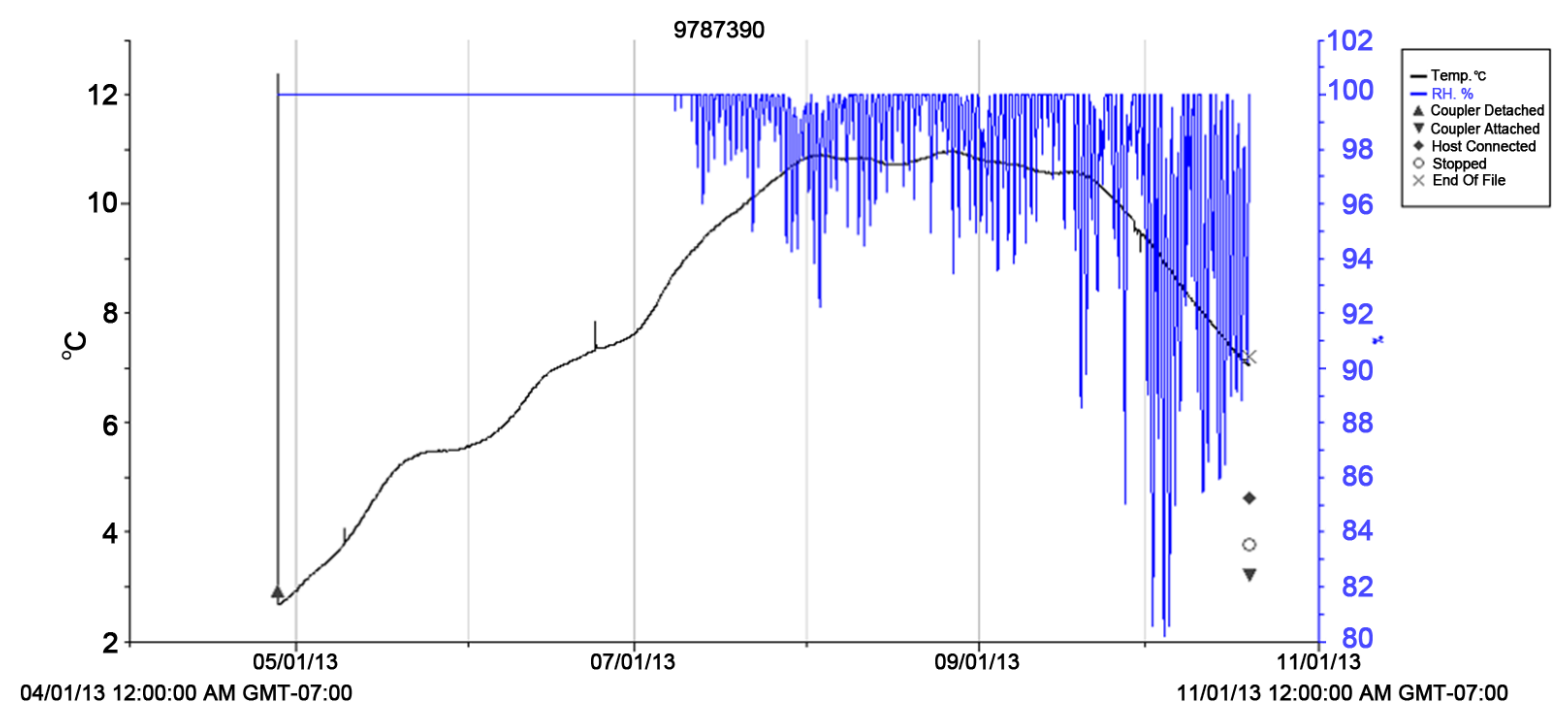

(b)

Figure 15. Temperature and relative humidity measured at the instrument site in a lodgedpole pine stand near Johnson Meadow (UTM 0614081 E, 4791159 N, Zone 10) between 27-April and 19 October-2013. The graph in Figure 15(a) presents data for $50 \mathrm{~cm}$ bgs. The graph in Figure 15(b) presents data for $95 \mathrm{~cm}$ bgs. 


\section{Wilshire Depth versus Temperature for}

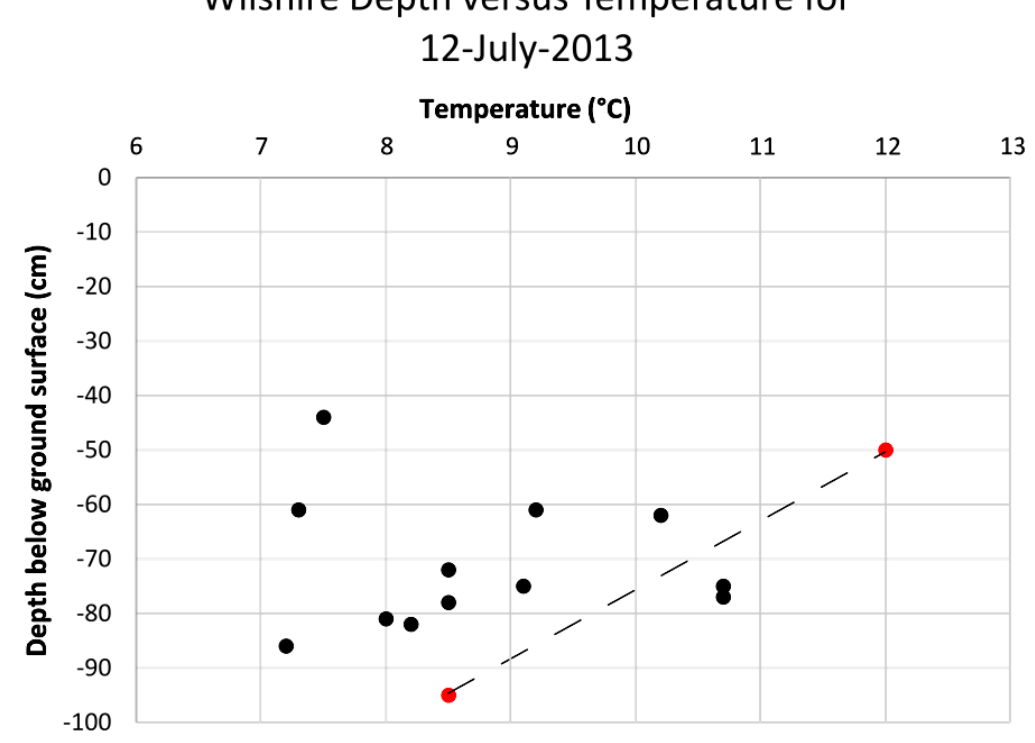

Figure 16. Temperature versus depth plot for Wilshire fen on 12-July-2013. The red dots connected by a dashed line are the temperatures at $-50 \mathrm{~cm}$ bgs and -95 $\mathrm{cm}$ bgs at the instrument site for the same date. The Wilshire fen is south facing and exposed to direct sunlight. The instrument site is located in lodgepole pine forest with mottled shade.

the pumice aquifer at Wilshire fen. Wilshire fen discharges from an exposed south-facing slope (Figure 3). The piezometric surface for all piezometers completed in the pumice aquifer was above the ground surface. At the control site in mottled shade on that date, the probe located $50 \mathrm{~cm}$ bgs recorded $12.0^{\circ} \mathrm{C}$ and the probe located at $95 \mathrm{~cm}$ bgs recorded $8.5^{\circ} \mathrm{C}$. The water table was more than $70 \mathrm{~cm}$ below the deepest probe. The piezometers with temperatures near the expected value for the depth of measurement compared to the instrument site were in the W6 cluster $\left(10.7^{\circ} \mathrm{C}\right.$ at $76 \mathrm{~cm}$ bgs $)$ which is located at the base of the slope in full sun. The lowest temperature for its depth $\left(7.5^{\circ} \mathrm{C}\right.$ at $44 \mathrm{~cm}$ bgs) was recorded in the deepest piezometer, W1-3.05 which was completed at $2.7 \mathrm{~m}$ bgs where refusal occurred. The relations between depth and water temperature at the Wilshire fen are similar to those measured at the Johnson fen and Dry Meadow fen. The relations are consistent with piezometric surfaces above the local ground surface and diffuse discharge of cool water from the fens.

\subsubsection{Electrical Conductivity}

At the Wilshire and Johnson fens electrical conductivity in peat and in the pumice aquifer indicates dilute (20.1 $40.0 \mu \mathrm{S} / \mathrm{cm}$ ) groundwater discharges at these sites. In piezometers screened in peat at Wilshire fen over $60 \%$ of measurements in WY11 through WY14 are within this range and over 90\% of measurements were less than 60.0 $\mu \mathrm{S} / \mathrm{cm}$. Conductivity values in peat less than $40 \mu \mathrm{S} / \mathrm{cm}$ were more common in WY11 - WY12 than in WY13 WY14. In piezometers completed in the pumice aquifer nearly 50\% of measurements in WY11 through WY14 were within this range and nearly $80 \%$ were less than $60.0 \mu \mathrm{S} / \mathrm{cm}$. In piezometers screened in peat at Johnson fen the greatest number of measurements fell within the $40.1-60.0 \mu \mathrm{S} / \mathrm{cm}$ range $(43.6 \%)$, but $90 \%$ were within the $20.1-60.0 \mu \mathrm{S} / \mathrm{cm}$ range. In piezometers completed in the pumice aquifer over 63\% were in the $20.1-40.0$ $\mu \mathrm{S} / \mathrm{cm}$ and over $94 \%$ fell within the range of $20.1-60.0 \mu \mathrm{S} / \mathrm{cm}$.

At both Wilshire and Johnson fens one piezometer cluster is distinctly different from all others. At Wilshire fen, the anomalous cluster is the W3 cluster completed in the pumice aquifer and farthest to the west near the alluvial fill of the valley which bounds the western edge of the fen (Figure 3). Electrical conductivity in the W3-1.4 piezometer was most commonly in the 295 to $145 \mu \mathrm{S} / \mathrm{cm}$ range with higher values in spring and early summer. Oxidation reduction potential (ORP) in this piezometer was generally less than $120 \mathrm{mV}$ and negative values were commonly recorded. A water sample collected on 6-November-2011 contained $20.4 \mathrm{mg} / \mathrm{l}$ iron (electrical conductivity $243 \mu \mathrm{S} / \mathrm{cm},-88 \mathrm{mV}=\mathrm{ORP}, 7.18=\mathrm{pH}$ ). The outer surface of the piezometer was coated with red/orange iron oxide. The neighboring piezometer, W3-1.0, has similar characteristics, but conductivity 
varies with season. Conductivity is commonly higher in April through July (120 to $220 \mu \mathrm{S} / \mathrm{cm}$ ) and lower (47 to $85 \mu \mathrm{s} / \mathrm{cm}$ ) in August through October. At Johnson fen, the picture is more complex. The J4-1.0 piezometer displayed distinctly higher electrical conductivity values in WY13 $(251.5-285.5 \mu \mathrm{S} / \mathrm{cm})$ and much lower values in WY14 (75.0 - $137.6 \mu \mathrm{S} / \mathrm{cm})$. Prior to WY13 values were similar to those measured in other piezometers at Johnson fen. In WY13 an iron film developed on the water surface within the piezometer. None was observed in WY14.

Patterns are less clear at the Dry Meadow fen. Overall, electrical conductivity is higher both in the peat layer and the pumice aquifer. In the peat, $47 \%$ of the measurement were between 40.1 and $80.0 \mu \mathrm{S} / \mathrm{cm}$ and nearly $20 \%$ were greater than $100.1 \mu \mathrm{S} / \mathrm{cm}$. In at least one cluster, the piezometer penetrated the boundary between the peat layer and underlying pumice deposit, but was screened in the peat layer. Piezometers into the pumice aquifer hit refusal in 5 of the 8 clusters [4]. In the pumice aquifer, only 41\% of measurements were between 40.1 and 80.0 $\mu \mathrm{S} / \mathrm{cm}$, and $36 \%$ were greater than $100.1 \mu \mathrm{S} / \mathrm{cm}$. In general, the Dry Meadow fen produces less surface discharge than the Wilshire and Johnson fens [4] and the piezometric surface for the pumice aquifer is above the local ground surface only in early summer $(<6 \mathrm{~cm}$ in area of most surface discharge in the central part of the fen).

\section{Discussion}

The fen systems and the groundwater-dependent ecosystems they support are the products of multiple inter-related factors. In this discussion we consider these factors and how they contribute to the fen systems. These factors include 1) low permeability regolith and bedrock units that underlie the pumice deposit, 2) lateral continuity of physical properties in the pumice deposit and settings that disrupt lateral continuity, and 3) elevation and its influence on snowpack and the freshet. A conceptual model that places fens in the context of landscape response to burial beneath nearly $3 \mathrm{~m}$ of pumice from the Mount Mazama eruption is presented.

\subsection{Low Permeability Regolith and Bedrock Units}

Returns from auger holes that intersected pre-eruption deposits and cores from monitoring wells drilled to approximately $30 \mathrm{~m}$ consistently indicated relatively low permeability regolith and bedrocks units underlie the area where pumice-hosted fens are present. These stratigraphic relations allow groundwater to accumulate in an unconfined perched pumice aquifer rather than infiltrate to deeper levels in the regolith and bedrock. However, two settings occur where groundwater flow pathways lie within the bedrock environment. These are 1) flow pathways at permeable interfaces within the bedrock stratigraphic section and 2) faults.

Groundwater flow pathways within the pre-eruption units are present in the phase 1 stratigraphic section and at the unconformity between phase 2 lava flows and regolith developed from phase 1 units. An example of flow pathways within the phase 1 stratigraphic section was provided by the 460 fen. There, peat desiccation in an elk wallow observed in WY2014 (July-September), loss of discharge from the stream channel where it passes through the lower fen, distribution of olivine basalt outcrops and inferred flow lobes (from topography), and rounded cobbles to boulders at the margin of the lower fen suggest a flow pathway controlled by stratigraphy in the phase 1 units. The post-eruption valley that hosts the upper fen crosses an exhumed stream channel that predates eruption of phase 1 basalt flows from a small shield volcano located north of the fen. An example of flow pathways along the unconformity between phase 2 lava flows and regolith developed from phase 1 units was provided by Johnson fen. There, the flow pathway appears to lie along the unconformity between the paleovalley formed by erosion of phase 1 units and olivine basalt flows of phase 2 that erupted onto the erosion surface and blocked the course of ancestral Jack Creek. The memory of the landscape that existed prior to eruption of the basalt flow(s) influences the subsurface migration of groundwater and is expressed at the Johnson fen and associated wetland fringes along the flow front of the basalt flow. In both of these examples, the groundwater discharge at the associated fens is a combination of groundwater moving within the unconfined pumice aquifer and groundwater flowing along permeable pathways in bedrock.

Discharge of deeper circulating groundwater into the pumice aquifer is documented at Johnson and Wilshire fens where higher electrical conductivity groundwater that is chemically distinct from groundwater in the pumice aquifer has been detected (Cummings, unpublished data). The volume of discharge is inferred to be small and to be focused along faults. The persistence of discharge detected at the W3-1.4 piezometer at Wilshire versus the episodic detection of discharge at Johnson fen and the Jack Creek fen at Skookum Butte is consistent 
with changing flow pathways along faults. In general, deep seated discharge is inferred to be a minor and locally occurring source of groundwater for the fens. This interpretation is further supported by the distribution of groundwater in monitoring wells that encountered small, bedrock-hosted, perched aquifers at intermediate depth, but the fractured and vesiculated olivine basalt flows and open-textured breccias encountered in the deep monitoring wells were dry.

\subsection{Lateral Continuity of Physical Properties in the Pumice Deposit}

The lateral continuity of physical properties within the pumice deposit reflects the depositional processes associated with subaerial fallout from Plinian eruptions. In addition to lateral continuity, the hydraulic conductivities determined for the pumice deposit are high. Aldous and Gurrieri [4] reported average hydraulic conductivity for the pumice deposit as $21.2 \mathrm{~m} / \mathrm{d}$. However, in the low slope environments found in the study area, wherever lateral permeability is blocked by iron oxide cementation, contacts with fine-grained alluvium, or peat, water becomes trapped in the pumice and discharge takes place slowly over a diffuse area. The hydraulic conductivity estimated for peat at the fen sites by Aldous and Gurrieri [4] was $0.24 \mathrm{~m} / \mathrm{d}$. Where piping has produced vertical permeability through peat, discharge at the surface is focused and streams carry water across the peat surface.

Peat is the most common agent restricting discharge at the pumice/peat interface. Contacts between finegrained alluvium and pumice is an important second agent restricting discharge from the aquifer. In most fens, peat is important across the fen surface and the contact with alluvium is important at the toe of the fen. Iron cementation commonly occurs in combination with the other two but was less easy to assess distribution and importance. Figure 5 illustrates where the toe of a fen is developed against iron-cemented pumice rather than alluvium.

\subsection{Elevation and Its Influence on Snowpack and the Freshet}

The final important factor that controls the distribution of fens in the Walker Rim field area is elevation. Elevation is important because of its influence on precipitation, particularly snowpack and the dynamics of the freshet. There are no data that allow the difference in snowpack to be determined between the Chemult Alternate SNOTEL site and Walker Rim study area. The 30-year average at the Chemult Alternate SNOTEL site is 69.8 cm [14]. The precipitation in the Walker Rim field area is estimated at greater than $76 \mathrm{~cm}$ [6] and greater than $80 \mathrm{~cm}$ per year [16], somewhat higher than at the Chemult Alternate SNOTEL (station 395) site [14]. The presence of fens at elevations greater than $1585 \mathrm{~m}$ suggests the annual precipitation received by the Walker Rim field area along with the low slope, characteristics of the pumice aquifer, low permeability bedrock and regolith, and development of permeability barriers by peat deposition, pumice-alluvium contacts, and iron cementation all contribute to the conditions that cause pumice-hosted fens to be important and distinctive components of this landscape.

\subsection{Conceptual Landscape Response Model}

The pumice-hosted fens in the Walker Rim study area reflect interactions among snowpack and the spring freshet, the relatively low permeability regolith and bedrock that restricts vertical passage of water, low slopes, lateral continuity of physical properties in the pumice deposit, and settings where the lateral continuity has been disrupted. The conceptual model of landscape response to the rapid loading of this landscape by pumice relies on feedback processes between the pumice deposits, evolving ground- and surface-water systems, and biological response through time to produce the fens in the modern landscape.

The starting point for the conceptual model is the end of the climactic eruption which blanketed the landscape with 2.7 to $3.0 \mathrm{~m}$ of dry pumice. Settling of fine particles from the atmosphere after the eruption and rain beat reduced infiltration into the pumice deposit. As a result, during spring snow melt, runoff was directed according to slopes which mimic the morphology of the pre-eruption landscape. Sheet flow and rilling on gentle to moderate slopes directed water across the low relief landscape toward valleys where incision through the surface crust re-directed flow. Beneath the surface crust was coarse, dry pumice of the upper pumice unit that could float and be transported through the nascent stream system where abrasion reduced grain size, released phenocrysts, and increased the fine-grained fraction in the suspended and bed load. During the early phase of down cutting, deposition of silt and rounded pumice took place where slope decreased-large low-land meadow environments. However, where slope was slightly greater lithics and phenocrysts from the primary pumice deposit 
and phenocrysts liberated from pumice during transport accumulated as a lag deposit. As the infiltration of melt water increased less water was delivered by overland flow to stream valleys. As a result, sand deposits that were bed load during the period of higher surface discharge became buried beneath rounded pumice, sand, and minor silt which through time graded upward into silty sand with pumice to sandy silt with rounded pumice to silt with sparse rounded pumice.

Although the newly emerging surface drainage system was controlled by the pre-eruption topography, the footprint of the evolving system was neither the same size nor necessarily the same orientation as the pre-eruption valley systems. The groundwater system, however, was more responsive to the pre-eruption landscape and to the distribution of permeable zones within the phase 1 and phase 2 bedrock units. As a result, areas of diffuse groundwater discharge emerged from the banks of the ephemeral stream valleys providing wet environments through the dry summer months. The combination of gentle slopes, accumulation of alluvium in the valleys, and colonization of wet banks by vegetation allowed groundwater-dependent ecosystems of the fen environments observed in the modern landscape to develop.

\section{Conclusion}

Pumice-hosted fens in the Walker Rim study area reflect complex interactions among bedrock, pumice, peat, alluvium, slope, and elevation. Bedrock and regolith are characterized by low permeability which restricts water movement downward from the pumice aquifer. The pumice aquifer has laterally homogenous characteristics except where it has been disrupted by incision of ephemeral stream valleys. Groundwater responding to preeruption landscape features discharged through erosion surfaces developed where ephemeral streams cut into the pumice deposit soon after the eruption. Where groundwater discharge occurred, groundwater dependent ecosystems were established and contributed the organic material needed for peat formation. Alluvium deposition in ephemeral stream valleys contributed additional lateral permeability barriers at the toe of slopes where fens were developing. The source of the groundwater discharging at fens is predominantly snowmelt which travels through the pumice aquifer and locally along permeable pathways in shallow bedrock. Deeper seated groundwater is locally contributed to fens along faults.

\section{References}

[1] Cummings, M.L. and Conaway, J.S. (2009) Landscape and Hydrologic Response in the Williamson River Basin Following the Holocene Eruption of Mount Mazama, Cascade Volcanic Arc. GSA Field Guides, 15, 271-294.

[2] Cummings, M.L. (2007) Groundwater Capture of Surface Drainage during Post-Eruption Landscape Evolution, Williamson River Basin, Oregon. Hydrological Science and Technology, 23, 79-90.

[3] Lind (2009) Holocene Floodplain Development of the Lower Sycan River, Oregon. M.S. Thesis, University of Oregon, Eugene.

[4] Aldous, A. and Gurrieri, J. (2011) Environmental Flows and Levels for Groundwater-Dependent Fens of the Antelope Grazing Allotment, Fremont-Winema National Forest, Oregon. The Nature Conservancy/United States Forest Service.

[5] Colman, S.M., Bradbury, J.P., McGeehin, J.P., Holmes, D.E., Edginton, D. and Sarna-Wojcicki, A. (2004) Chronology of Sediment Deposition in Upper Klamath Lake, Oregon. Journal of Paleolimnology, 31, 139-149. http://dx.doi.org/10.1023/B:JOPL.0000019234.05899.ea

[6] Gannett, M.W., Lite Jr., K.E., La Marche, J.L., Fisher, B.J. and Polette, D.H. (2007) Groundwater Hydrology of the Upper Klamath Basin, Oregon and California. US Geological Survey Scientific Investigations Report 2007-5050.

[7] Bacon, C.R. and Lanphere, M.A. (2006) Eruptive History and Geochronology of Mount Mazama and the Crater Lake Region, Oregon. Geological Society of America Bulletin, 118, 1331-1359. http://dx.doi.org/10.1130/B25906.1

[8] Zdanowicz, C.M., Zielinski, G.A. and Germani, M.S. (1999) Mount Mazama Eruption: Calendrical Age Verified and Atmospheric Impact Assessed. Geology, 27, 621-624. http://dx.doi.org/10.1130/0091-7613(1999)027<0621:MMECAV>2.3.CO;2

[9] Young, S.R. (1990) Physical Volcanology of Holocene Airfall Deposits from Mt. Mazama, Crater Lake, Oregon. Ph.D. Dissertation, University of Lancaster, Lancaster.

[10] Fisher, R.V. and Schmincke, J.-U. (1984) Pyroclastic Rocks. Springer-Verlag, Berlin. http://dx.doi.org/10.1007/978-3-642-74864-6

[11] Klug, C., Cashman, K.V. and Bacon, C.R. (2002) Structure and Physical Characteristics of Pumice from the Climactic Eruption of Mount Mazama (Crater Lake). Bulletin of Volcanology, 64, 486-501. 
http://dx.doi.org/10.1007/s00445-002-0230-5

[12] Manville, V., White, J.D.L., Houghton, B.F. and Wilson, C.J.N. (1998) The Saturation Behaviour of Pumice and Some Sedimentological Implications. Sedimentary Geology, 119, 5-16. http://dx.doi.org/10.1016/S0037-0738(98)00057-8

[13] Gusey, D.L. (2010) Drilling Report Antelope Groundwater Monitoring Wells Chemult Ranger District-FremontWinema National Forest. US Forest Service Internal Report.

[14] http://www.nrcs.usda.gov/wps/portal/nrcs/detail/or/snow/?cid+nrc

[15] Cummings, M.L., Large, A., Mowbray, A., Weatherford, J. and Webb, B. (2013) Fens, Seasonal Wetlands, and the Unconfined Pumice Aquifer East of the Cascade Range, South-Central Oregon. 2013 Fall Meeting American Geophysical Union, San Francisco, 9-13 December 2013.

[16] Palmer, C.S., Gannett, M.W. and Hinkle, S.R. (2007) Isotopic Characterization of Three Groundwater Recharge Sources and Inferences for Selected Aquifers in the Upper Klamath Basin of Oregon and California, USA. Journal of Hydrology, 336, 17-29. http://dx.doi.org/10.1016/j.jhydrol.2006.12.008 
Scientific Research Publishing (SCIRP) is one of the largest Open Access journal publishers. It is currently publishing more than 200 open access, online, peer-reviewed journals covering a wide range of academic disciplines. SCIRP serves the worldwide academic communities and contributes to the progress and application of science with its publication.

Other selected journals from SCIRP are listed as below. Submit your manuscript to us via either submit@scirp.org or Online Submission Portal.
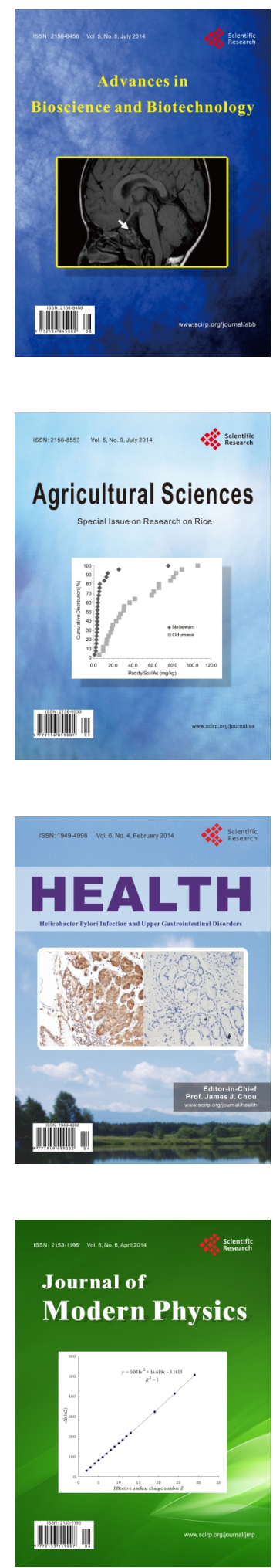
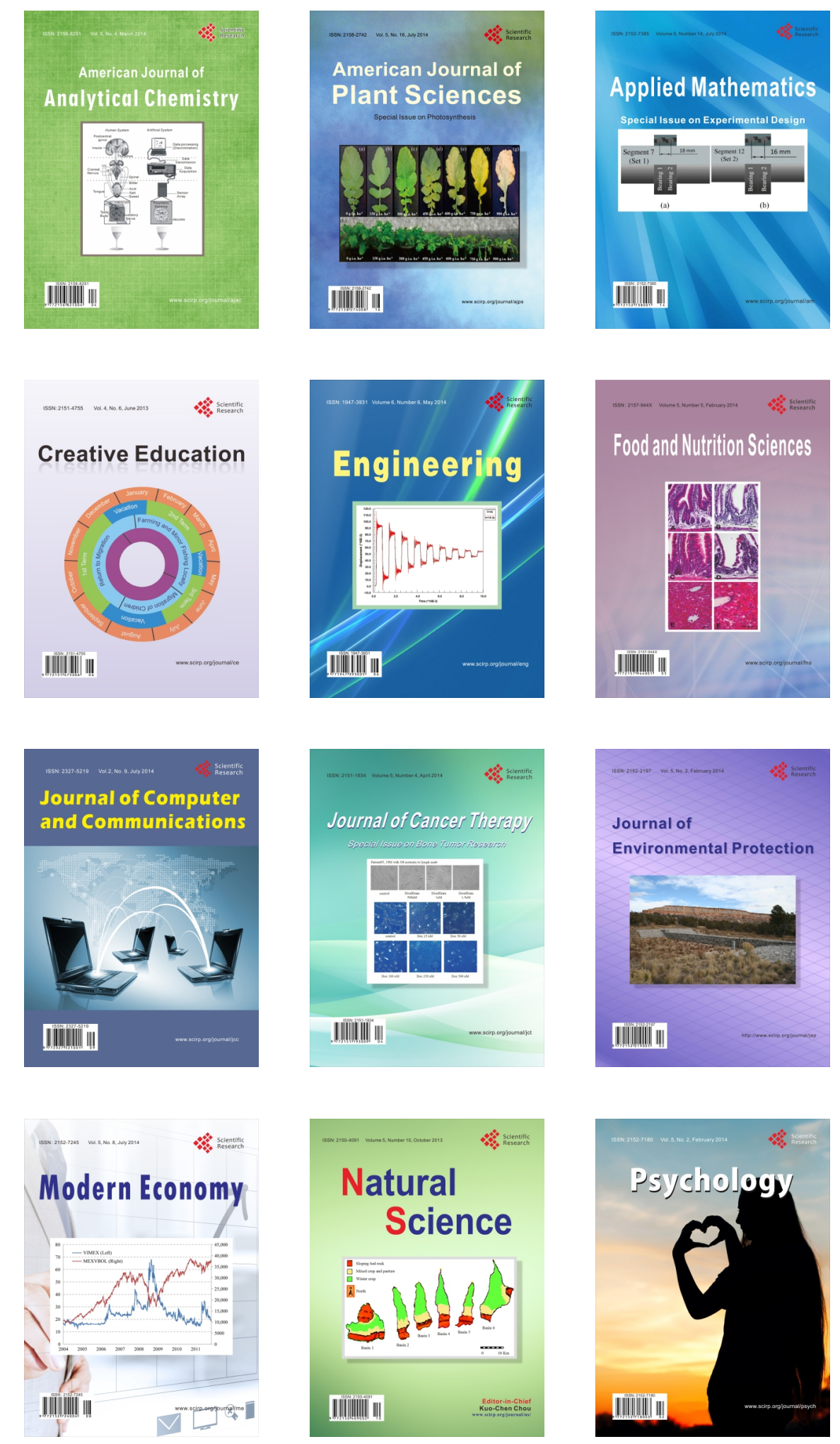